Keywords: Nepheline, $C C C$, Crystallization, DWPF

Retention: Permanent

\title{
The Impact of Kinetics on Nepheline Formation in Nuclear Waste Glasses
}

J.W. Amoroso

March 2011

Savannah River National Laboratory Savannah River Nuclear Solutions, LLC Aiken, SC 29808

Prepared for the U.S. Department of Energy under contract number DE-AC09-08SR22470.

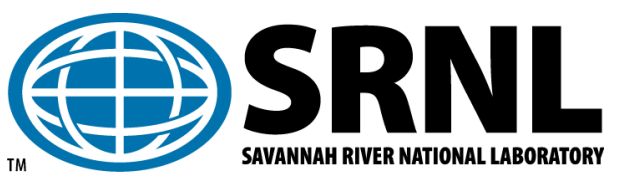


SRNL-STI-2011-0051

Revision 0

\section{DISCLAIMER}

This work was prepared under an agreement with and funded by the U.S. Government. Neither the U.S. Government or its employees, nor any of its contractors, subcontractors or their employees, makes any express or implied:

1. warranty or assumes any legal liability for the accuracy, completeness, or for the use or results of such use of any information, product, or process disclosed; or

2. representation that such use or results of such use would not infringe privately owned rights; or

3. endorsement or recommendation of any specifically identified commercial product, process, or service.

Any views and opinions of authors expressed in this work do not necessarily state or reflect those of the United States Government, or its contractors, or subcontractors.

\section{Printed in the United States of America}

Prepared for

U.S. Department of Energy 


\section{EXECUTIVE SUMMARY}

Sixteen glass compositions were selected to study the potential impacts of the kinetics of nepheline formation in high-level nuclear waste (HLW) glass. The chosen compositions encompassed a relatively large nepheline discriminator (ND) range, $0.40-0.66$, and included a relatively broad range, and amount of, constituents including high aluminum and high boron concentrations. All glasses were fabricated in the laboratory and subsequently exposed to six different cooling treatments. The cooling treatments consisted of three 'stepped' profiles and their corresponding 'smooth' profiles. Included in the cooling treatment was the Defense Waste Processing Facility (DWPF) canister centerline cooling (CCC) profile in addition to a "faster" and a "slower" total cooling line. After quenching and heat treating, x-ray diffraction confirmed the type and amount of any resultant crystallization.

The target compositions were shown to be consistent with the measured compositions. Two quenched glasses and several treated glasses exhibited minor amounts of spinel and spinel-like phases. Nepheline was not observed in any of the quenched glasses but was observed in many of the treated glasses. The amount of nepheline ranged from approximately $2 \mathrm{wt} \%$ to $30 \mathrm{wt} \%$ for samples cooled over shorter times and longer times respectively.

Differences were observed in the amount of nepheline crystallization after smooth and stepped cooling and increased with total cooling time. In some glasses, nepheline crystallization appeared to be directly proportional to total cooling time while the total amount of nepheline crystallization varied, suggesting that the nepheline crystallization rate was independent of (or at least faster than) cooling rate but, varied depending on the glass composition. On the contrary, in another glass, nepheline crystallization appeared to be inversely proportional to cooling rate. The high alumina glasses, predicted to form nepheline according to the ND, did not precipitate nepheline.

Additionally, analysis from different regions of treated glasses indicated that nepheline nucleation and growth occurs at the glass/crucible and glass/atmosphere interfaces. Furthermore, the measured amount of non-nepheline phases appeared independent of the sampling region. It is postulated that crucible-scale methods used to heat treat HLW glass, such as the CCC method, artificially induce nepheline formation in the glass.

The results of this study suggest nepheline kinetics can vary significantly depending on glass composition and, more importantly, glasses fabricated using current DWPF conditions are potentially susceptible to the impact of nepheline kinetics. This report summarizes the supporting research and provides the basis for continued research on nepheline kinetics and its effects on HLW glasses. 


\section{TABLE OF CONTENTS}

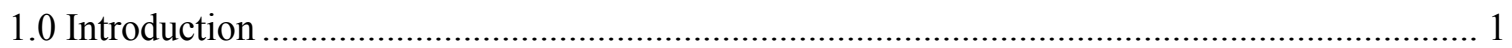

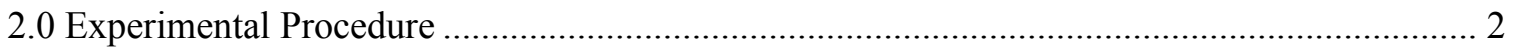

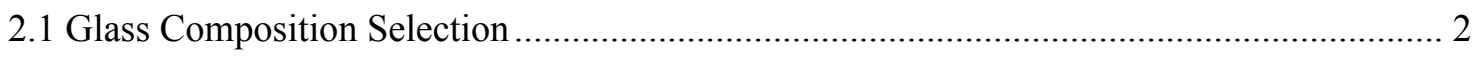

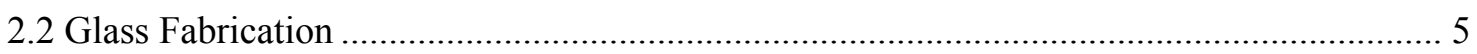

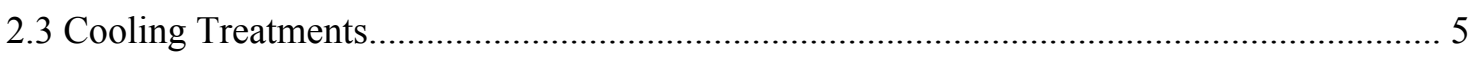

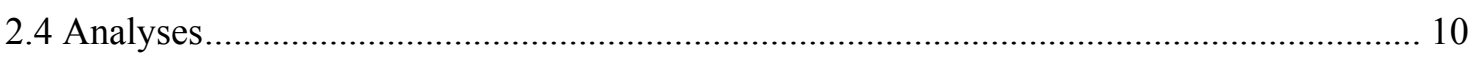

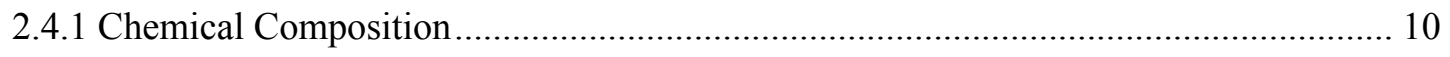

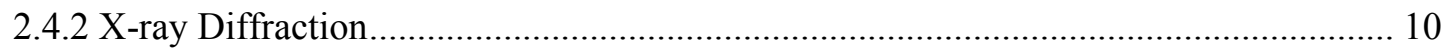

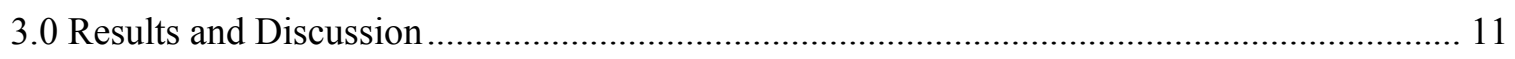

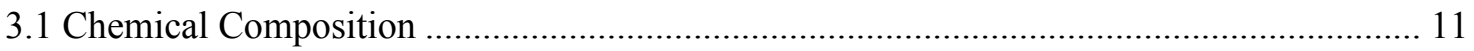

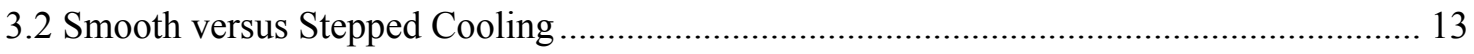

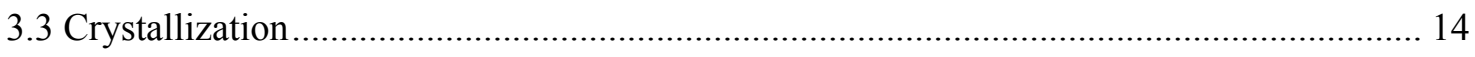

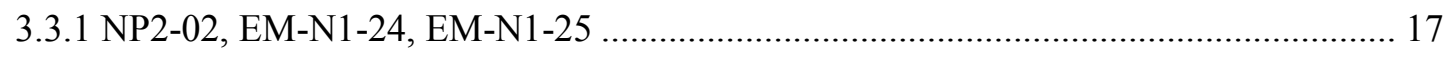

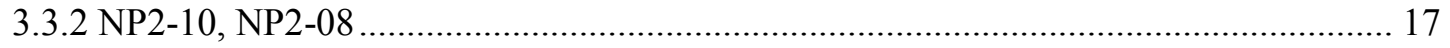

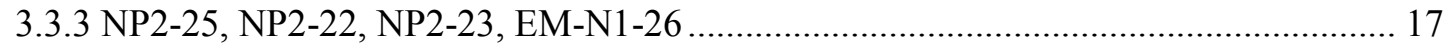

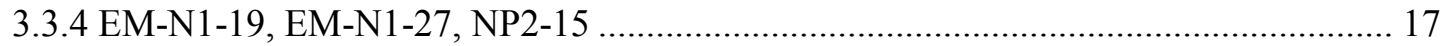

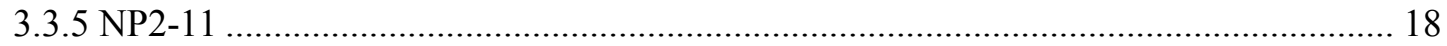

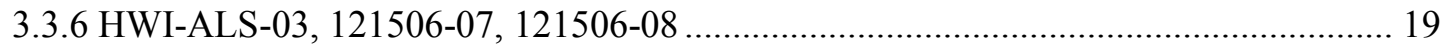

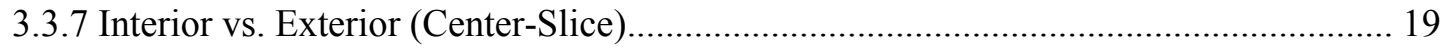

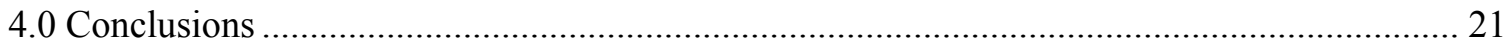

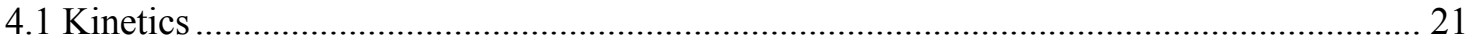

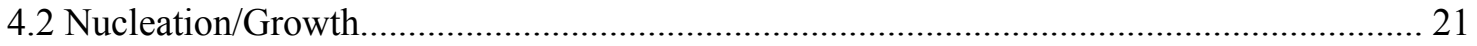

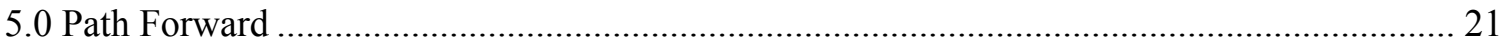

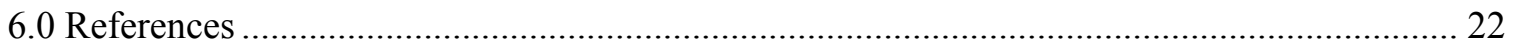

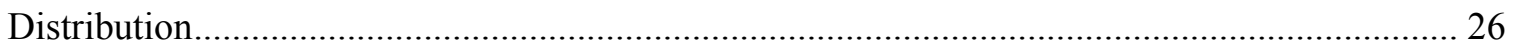




\section{LIST OF TABLES}

Table 2-1. Source of Samples and Associated Selection Criteria.............................................. 3

Table 2-2. Target Compositions for Test Glasses.................................................................... 4

Table 2-3. Target Setpoints and Cooling Rates Used for Smooth Cooling Schedules............... 8

Table 2-4. Target Setpoints, Cooling Rates, and Dwell Times Used for Stepped Cooling

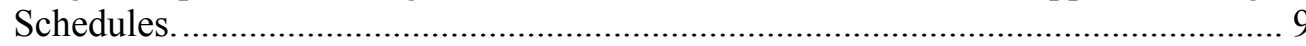

Table 3-1. Target and Measured Chemical Composition of Glasses....................................... 12

Table 3-2. Calculated Nepheline Phase Concentrations: Smooth Cooling Minus Stepped

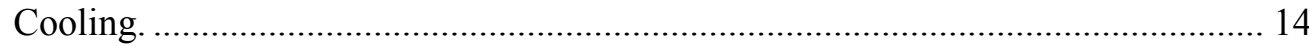

Table 3-3. Calculated Non-Nepheline Phase Concentrations: Smooth Cooling Minus

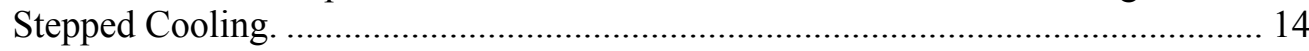

Table 3-4. Qualitative XRD Results for Quenched and Center-Slice Samples. ........................ 15

Table 3-5. Quantitative* XRD Results for Quenched and Center-Slice Samples...................... 16

Table 3-6. Qualitative XRD Results for Interior and Center-Slice Sections for CCC-3 and CCCR-3 Cooling Treatments. ...................................................................... 20

\section{LIST OF FIGURES}

Figure 1. Temperature Along the Canister (B-49) Centerline During SGM-8. ${ }^{14}$ (Note That the Data at the Start of the Pour Has Been Removed for Clarity.) ............................. 5

Figure 2. Plot of TC-4 Temperature Data From Canister B- $49^{14}$ During Pour and Cool

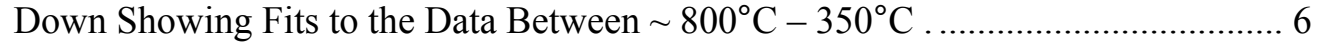

Figure 3. Target Cooling Profiles Used to Treat Glasses........................................................ 7

Figure 4. Process Steps Involved in Preparing 'Center-Slice' and 'Interior' Samples for

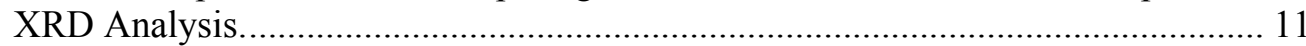

Figure 5. Recorded Temperatures of the Glass and Furnace During Laboratory Smooth CCC (CCCR-3) Compared to Canister (B-49) Filling Thermocouple Data ${ }^{14}$. e. .... 13

Figure 6. Percent Crystal Phases as a Function of Total Cooling Time for A) NP2-15, B) EM-N1-19, and C) EM-N1-27.

Figure 7. Percent Nepheline in NP2-11 After Cooling Treatments as a Function of A) Cooling Rate* and B) Total Cooling Time.

Figure 8. A) Schematic Representation of the Cross Section of a Glass in a Crucible After Cooling Treatment. B) Photograph of NP2-22 Thin Section After CCC-1 


\section{LIST OF ABBREVIATIONS}

$\begin{array}{ll}\text { AD } & \text { Analytical Development } \\ \text { CCC } & \text { Canister Centerline Cooling } \\ \text { DWPF } & \text { Defense Waste Processing Facility } \\ \text { g } & \text { gram(s) } \\ \text { HLW } & \text { High Level Nuclear Waste } \\ \text { ICP }- \text { AES } & \text { Inductively Couple Plasma - Atomic Emission Spectroscopy } \\ \text { LM } & \text { Lithium Metaborate Fusion } \\ \text { ND } & \text { Nepheline Discriminator } \\ \text { OB } & \text { Optical Basicity } \\ \text { PCT } & \text { Product Consistency Test } \\ \text { PF } & \text { Peroxide Fusion } \\ \text { PNNL } & \text { Pacific Northwest National Lab } \\ \text { SGM } & \text { Scale Glass Melter } \\ \text { VSL } & \text { Vitreous State Laboratory } \\ \text { XRD } & \text { X-Ray Diffraction }\end{array}$




\subsection{Introduction}

The acceptability of high-level nuclear waste (HLW) glass as a suitable waste form is dependent on its durability as measured by the Product Consistency Test (PCT). However, it is well know that volume fractions of additional phases present in HLW glass can adversely affect their measured PCT responses. ${ }^{1-3}$ The PCT is performed on both quenched and Canister Centerline Cooled (CCC) glasses to "bound" the thermal history impacts on possible PCT performance issues for a given glass. The reason for this is that during the pouring of canisters, the HLW glass is subjected to relatively slow cooling during which, it is possible to precipitate various crystalline species.

Historically, nepheline $\left(\mathrm{NaAlSiO}_{4}\right)$ has been studied in HLW glass because of its potential negative impact on the PCT response. ${ }^{2,4,5}$ The impact of nepheline on the PCT response of HLW glasses was the basis for the nepheline discriminator (ND), a constraint developed by Pacific Northwest National Laboratory (PNNL) ${ }^{5}$ that is used by the Defense Waste Processing Facility (DWPF) as a process control constraint to prevent nepheline crystallization. The ND was developed as a compositional constraint for HLW glasses exposed to CCC in order to simulate a worst-case kinetic state ${ }^{*}$. Therefore, the ND is a compositional constraint that applies to one kinetic state or to be precise, the CCC kinetic state.

If the nepheline primary phase field in the $\mathrm{SiO}_{2}-\mathrm{Al}_{2} \mathrm{O}_{3}-\mathrm{Na}_{2} \mathrm{O}$ system is considered, the ND states that if the $\mathrm{SiO}_{2}$ content of the $\mathrm{SiO}_{2}, \mathrm{Al}_{2} \mathrm{O}_{3}$, and $\mathrm{Na}_{2} \mathrm{O}$ sub-mixture is greater than 62 mass\% in the final glass, nepheline is unlikely to form. ${ }^{1}$ Consequently, from a compositional standpoint the ND is a significant impediment to achieving higher waste loadings, particularly for waste high in aluminium and sodium.

Prompted by higher waste loading projections and/or requirements, much research at PNNL and SRNL (whether explicitly or inexplicitly) has been focused on identifying conservatism in the ND constraint in an attempt to revise/modify the ND, thus allowing access to functional compositional space that is currently inaccessible based on the current ND constraint. To date, the majority of these studies have focused on compositional effects to identify potential conservatism in the current ND. ${ }^{2-4,6-8}$ In general, these studies have suggested that particular oxides $\left(\mathrm{B}_{2} \mathrm{O}_{3}\right.$ and $\left.\mathrm{CaO}\right)$ suppress nepheline crystallization; however, persuasive data to constitute modification of the current ND has not been forthcoming. McCloy et al. ${ }^{9}$ has proposed that an additional constraint, optical basicity (OB), be used to complement the ND. That OB model uses a modified electronegativity approach to rank constituent oxides according to their propensity to disassociate and has been used to describe the effects of $\mathrm{B}_{2} \mathrm{O}_{3}$ and $\mathrm{CaO}$ on nepheline crystallization in HLW glasses.

Although there is much to be learned from compositional studies, any results obtained will be dependent on the thermal history of the glass. Likewise, it is well known that the current ND is based on a constant kinetic term, yet seemingly little research has explored nepheline kinetics as a means to reduce conservatism in and/or modify the ND. Menkhaus et al. ${ }^{1}$ have suggested that nepheline kinetics is extremely rapid in HLW glasses which may be one reason for the lack of kinetic studies. Nevertheless, in order to achieve higher waste loadings, particularly for high aluminium and sodium wastes, reducing conservatism in the ND is required. Additionally, as

\footnotetext{
* Here, and throughout the document, the term 'kinetic state' refers to the collective thermal history of the glass and is meant to convey to the reader that the temperature(s), and duration at the respective temperature(s), of the glass during pouring and throughout cooling may vary, thus leading to different thermal/kinetic environments which, in tern could lead to varying amounts of crystallization propensity.
} 
waste loading requirements continue to increase it is likely that production rates will increase as well, leading to changes in the cooling rates, times, and temperatures of the waste glass in the canister. It is foreseeable that under different kinetic states (cooling rates, times, and temperatures) conservatism in the current ND could be exploited.

To that end, this study was devised to explore the kinetics of nepheline formation and the impacts on HLW crystallization. Nepheline kinetics were explored by subjecting glass samples to three different cooling schedules and comparing smooth profile cooling to stepped profile cooling. This report attempts to provide data to support the importance of kinetics in predicting nepheline formation in HLW glasses and provide a basis for continued research on nepheline kinetics and its effects on HLW glass crystallization.

\subsection{Experimental Procedure}

\subsection{Glass Composition Selection}

The glass compositions for this study were deliberately chosen from previous studies. This was done for various reasons listed below:

- Added additional information/data to previous studies/glasses rather than generating an entirely new data set.

- Made it possible to select glasses based on composition, nepheline discriminator (ND) values, and type of crystallization, simultaneously.

- Provided a reference point for comparison.

- Reduced the number of glasses necessary to study.

Ultimately, sixteen glass compositions were selected from previous studies including, eight from Fox's NP2 study ${ }^{7}$, two from Fox's high alumina study ${ }^{10}$, five from Billings' EM-N1 study ${ }^{6}$, and one from a Vitreous State Laboratory (VSL) study. ${ }^{1}$ The eight NP2 and five EM-N1 glass compositions were chosen because these compositions challenged the ND and/or they were reported to be amorphous, contain nepheline (in the absence of other crystal phases), or contain nepheline and another spinel-like phase upon CCC. This selection criteria was based on the hypothesis that nepheline kinetics could be utilized to force crystallization to occur in some of these glasses by cooling them slower or suppress crystallization by cooling them faster.

The two glass compositions from Fox ${ }^{10}$ and one from VSL ${ }^{11}$ were chosen because they represented high alumina glasses, but did not form nepheline after CCC. Of note, Fox's high alumina glasses originally contained small amounts of cadmium and fluorine; however, for this study, the cadmium and fluorine were removed and the remaining constituents were renormalized to obtain $100 \%$ (by weight). Table 2-1 summarizes the glass ID's, and their associated selection criteria used in this study. Table 2-2 lists the target compositions for the sixteen test glasses. 
Table 2-1. Source of Samples and Associated Selection Criteria

\begin{tabular}{|c|c|c|c||}
\hline Glass ID & ND & $\begin{array}{c}\text { Reported } \\
\text { Phases After } \\
\text { CCC }\end{array}$ & Reference \\
\hline NP2-11 & 0.51 & Nepheline Only & 1 \\
\hline NP2-15 & 0.49 & Nepheline Only & 1 \\
\hline NP2-10 & 0.65 & Amorphous & 1 \\
\hline NP2-08 & 0.66 & Amorphous & 1 \\
\hline NP2-25 & 0.60 & Amorphous & 1 \\
\hline NP2-02 & 0.66 & Amorphous & 1 \\
\hline NP2-22 & 0.60 & Nepheline Only & 1 \\
\hline NP2-23 & 0.60 & Nepheline Only & 1 \\
\hline $\mathbf{1 2 1 5 0 6 - 0 7}$ & 0.40 & Magnetite/Spinel & 2 \\
\hline 121506-08 & 0.42 & Magnetite/Spinel & 2 \\
\hline HWI-ALS-03 & 0.54 & Magnetite/Spinel & 4 \\
\hline EM-N1-24 & 0.59 & Amorphous & 3 \\
\hline EM-N1-25 & 0.62 & Amorphous & 3 \\
\hline EM-N1-26 & 0.60 & Nepheline/Spinel & 3 \\
\hline EM-N1-27 & 0.58 & Nepheline/Spinel & 3 \\
\hline
\end{tabular}


Table 2-2. Target Compositions for Test Glasses

\begin{tabular}{|c|c|c|c|c|c|c|c|c|c|c|c|c|c|c|c|c|c|c|c|c|c|c|c|}
\hline NP2-11 & $\underset{\infty}{8}$ & $\begin{array}{l}\& \\
\pm \\
\pm\end{array}$ & & & & & స్ ָ̊ & & $\begin{array}{l}\infty \\
\infty \\
i n\end{array}$ & & & ô & & $\begin{array}{l}n \\
\dot{+}\end{array}$ & $\underset{m}{\stackrel{m}{n}}$ & & & & $\begin{array}{l}8 \\
\dot{m} \\
m\end{array}$ & & & & \\
\hline NP2-15 & $\begin{array}{l}8 \\
\infty \\
\infty \\
-\end{array}$ & $\begin{array}{l}8 \\
\dot{ \pm}\end{array}$ & & & & & & & $\stackrel{8}{i}$ & & & $\underset{+}{\stackrel{+}{+}}$ & $\stackrel{n}{\rightarrow}$ & in & $\begin{array}{l}\underset{\infty}{\infty} \\
\infty \\
\infty\end{array}$ & in & & & $\begin{array}{l}8 \\
\dot{m} \\
m\end{array}$ & & $\stackrel{n}{n}$ & & \\
\hline NP2-10 & $\begin{array}{l}n \\
\stackrel{0}{0} \\
0\end{array}$ & $\stackrel{7}{9}$ & & & $\stackrel{\circ}{o}$ & & & & $\begin{array}{l}\vec{t} \\
\stackrel{d}{\rightarrow}\end{array}$ & & & $\begin{array}{l}0 \\
\stackrel{1}{n}\end{array}$ & $\stackrel{\infty}{0}$ & in & $\stackrel{?}{\stackrel{f}{g}}$ & & & & $\begin{array}{l}\mathcal{O} \\
\stackrel{f}{f}\end{array}$ & & & & \\
\hline NP2-08 & $\hat{\sigma}$ & 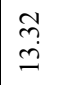 & & & $\stackrel{8}{\stackrel{+}{+}}$ & & & & 8 & & & $\stackrel{8}{\circ}$ & & $\underset{\sim}{\sigma}$ & $\begin{array}{l}\infty \\
\stackrel{\infty}{n} \\
\end{array}$ & & & & $\underset{\stackrel{P}{j}}{\stackrel{y}{y}}$ & & $\underset{i}{\stackrel{8}{i}}$ & & \\
\hline NP2-25 & 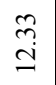 & $\underset{\infty}{\infty}$ & & & $\stackrel{\infty}{n}$ & & ठे. & & $\stackrel{\infty}{a}$ & & & $\tilde{m}_{i}$ & $\tilde{n}$ & $\stackrel{\infty}{i}$ & 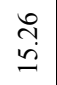 & $\stackrel{0}{0}$ & & & 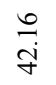 & & 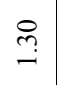 & & \\
\hline NP2-02 & $\underset{ָ}{N}$ & $\begin{array}{l}\stackrel{8}{ \pm} \\
\dot{ \pm}\end{array}$ & & & & & స్ ڤ్ & & $\stackrel{8}{i}$ & & & $\underset{+}{\stackrel{8}{+}}$ & & S. & $\begin{array}{l}\stackrel{8}{\infty} \\
\infty \\
\infty\end{array}$ & 8 & & & 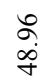 & & $\underset{i}{8}$ & & \\
\hline NP2-22 & $\begin{array}{l}\hat{a} \\
\mathrm{~g}\end{array}$ & 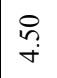 & & & ठ̊. & & $\stackrel{\text { Oे }}{0}$ & & $\stackrel{a}{\circ}$ & & & $\begin{array}{c}\hat{\infty} \\
\dot{+}\end{array}$ & & $\stackrel{\infty}{n}$ & $\begin{array}{l}8 \\
\infty \\
\infty\end{array}$ & તิ & & & $\begin{array}{l}\stackrel{n}{\stackrel{f}{f}} \\
\dot{f}\end{array}$ & & $\underset{i}{8}$ & & \\
\hline NP2-23 & $\begin{array}{l}\stackrel{\infty}{]} \\
\text { In }\end{array}$ & $\stackrel{\substack{n \\
+}}{ }$ & & & $\underset{+}{\stackrel{8}{+}}$ & & त్రి & & $\stackrel{\widetilde{N}}{\sim}$ & & & $\underset{+}{\stackrel{\leftrightarrow}{+}}$ & $\stackrel{n}{=}$ & $\stackrel{9}{=}$ & $\begin{array}{l}\stackrel{8}{0} \\
\infty \\
-1\end{array}$ & $\stackrel{5}{0}$ & & & 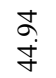 & & $\underset{i}{\stackrel{8}{i}}$ & & \\
\hline $121506-07$ & $\begin{array}{l}t \\
b \\
\text { i }\end{array}$ & $\begin{array}{l}\stackrel{8}{\infty} \\
\stackrel{\infty}{-}\end{array}$ & $\stackrel{0}{\circ}$ & $\stackrel{\vartheta}{=}$ & $\begin{array}{l}\stackrel{8}{ \pm} \\
\stackrel{+}{-}\end{array}$ & & tr & & $\frac{n}{6}$ & $\stackrel{R}{i}$ & & & $\stackrel{2}{\div}$ & & $\begin{array}{l}8 \\
\text { in }\end{array}$ & f̊. & $\stackrel{ }{=}$ & $\stackrel{?}{f}$ & $\underset{\vec{N}}{\vec{N}}$ & $\vec{\jmath}$ & $\overrightarrow{0}$ & $\stackrel{8}{0}$ & F. \\
\hline $121506-08$ & $\begin{array}{l}8 \\
\stackrel{i}{0} \\
\text {. }\end{array}$ & $\begin{array}{l}\vec{\sim} \\
\stackrel{\sim}{\sim}\end{array}$ & $\stackrel{0}{\circ}$ & 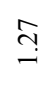 & ถి & & $\begin{array}{l}\infty \\
n \\
0\end{array}$ & & $\tilde{n}$ & $\stackrel{0}{\circ}$ & & $\underset{+}{\stackrel{+}{+}}$ & $\stackrel{m}{0}$ & & $\begin{array}{l}\infty \\
\infty \\
\infty\end{array}$ & $\stackrel{f}{\circ}$ & $\cong$ & $\stackrel{f}{f}$ & ते & $\begin{array}{l}\tilde{J} \\
0 \\
0\end{array}$ & $\stackrel{\Xi}{\circ}$ & $\stackrel{\circ}{0}$ & J \\
\hline HWI-ALS-03 & $\begin{array}{l}0 \\
\stackrel{n}{0} \\
\varrho\end{array}$ & 苞 & $\stackrel{\partial}{\circ}$ & & $\hat{n}$ & $\stackrel{8}{\circ}$ & $\stackrel{0}{\stackrel{0}{0}}$ & 苟 & $\stackrel{o}{a}$ & $\stackrel{\circ}{\circ}$ & $\stackrel{0}{0}$ & 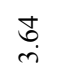 & $\stackrel{\infty}{\circ}$ & $\begin{array}{l}\infty \\
\infty \\
0\end{array}$ & $\stackrel{q}{q}$ & $\stackrel{n}{0}$ & & $\stackrel{\leftrightarrow}{0}$ & $\underset{n}{\vec{n}}$ & $\stackrel{0}{0}$ & $\stackrel{g}{g}$ & $\stackrel{t}{0}$ & तु \\
\hline EM-N1-19 & $\begin{array}{l}\stackrel{0}{0} \\
\stackrel{0}{-1}\end{array}$ & $\stackrel{\infty}{\stackrel{\leftrightarrow}{+}}$ & $\stackrel{7}{0}$ & & $\stackrel{\vec{b}}{-}$ & $\stackrel{n}{0}$ & त్రి & $\stackrel{5}{0}$ & $\stackrel{n}{\stackrel{n}{I}}$ & $\stackrel{0}{\stackrel{0}{0}}$ & $\stackrel{\infty}{\circ}$ & $\underset{i}{\stackrel{d}{i}}$ & $\stackrel{9}{0}$ & $\hat{s}$ & $\begin{array}{l}0 \\
\stackrel{\infty}{\infty}\end{array}$ & 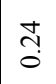 & & ठ. & $\stackrel{\stackrel{m}{\vec{f}}}{\vec{F}}$ & $\stackrel{\infty}{0}$ & ֻُ & $\stackrel{\simeq}{0}$ & ஸి \\
\hline EM-N1-24 & $\stackrel{n}{m}$ & $\begin{array}{l}\stackrel{n}{n} \\
+\end{array}$ & $\stackrel{\circ}{\circ}$ & & f & $\stackrel{m}{0}$ & $\stackrel{0}{0}$ & $\stackrel{8}{\circ}$ & $\begin{array}{l}\stackrel{2}{2} \\
\stackrel{2}{n}\end{array}$ & $\stackrel{ \pm}{\circ}$ & o. & 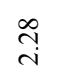 & $\frac{1}{0}$ & $\stackrel{?}{\stackrel{9}{-}}$ & $\stackrel{m}{\stackrel{\sim}{*}}$ & $\vec{\jmath}$ & & $\stackrel{\infty}{\circ}$ & $\begin{array}{l}\text { f } \\
\text { f }\end{array}$ & $\frac{0}{0}$ & $\exists$ & $\stackrel{\circ}{\circ}$ & స్ \\
\hline EM-N1-25 & $\stackrel{8}{\circ}$ & $\stackrel{\overbrace{}}{?}$ & $\overline{0}$ & & $\stackrel{\sim}{n}$ & $\frac{ \pm}{0}$ & $\frac{\partial}{0}$ & $\stackrel{5}{0}$ & $\stackrel{\infty}{\underset{\Xi}{ \pm}}$ & $\stackrel{n}{\circ}$ & $\stackrel{\infty}{\circ}$ & $\stackrel{R}{i}$ & $\frac{\infty}{0}$ & $\stackrel{\infty}{\infty}$ & $\stackrel{\infty}{\stackrel{\infty}{\leftrightarrows}}$ & สุ & & $\stackrel{\infty}{\circ}$ & $\begin{array}{l}\underset{y}{y} \\
\text { zy }\end{array}$ & $\frac{1}{0}$ & $\stackrel{\infty}{\rightleftarrows}$ & $\overline{0}$ & के \\
\hline EM-N1-26 & $\begin{array}{l}\stackrel{8}{0} \\
\stackrel{0}{-}\end{array}$ & $\stackrel{\infty}{\stackrel{\leftrightarrow}{+}}$ & $\frac{7}{0}$ & & $\stackrel{b}{-}$ & $\stackrel{2}{\circ}$ & त్రి & $\hat{\circ}$ & $\begin{array}{l}\vec{\Xi} \\
\stackrel{\vec{n}}{ }\end{array}$ & $\frac{0}{0}$ & $\stackrel{\infty}{\circ}$ & in & $\frac{9}{0}$ & $\hat{a}$ & $\begin{array}{l}n \\
\stackrel{n}{\epsilon} \\
=\end{array}$ & $\stackrel{t}{\stackrel{d}{o}}$ & & $\stackrel{\circ}{\circ}$ & $\stackrel{5}{\stackrel{f}{q}}$ & $\stackrel{\infty}{0}$ & 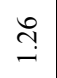 & $\stackrel{2}{0}$ & $\stackrel{m}{3}$ \\
\hline EM-N1-27 & $\stackrel{\vec{g}}{=}$ & 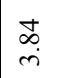 & $\stackrel{9}{0}$ & & $\stackrel{I}{-}$ & $\begin{array}{l}0 \\
\stackrel{0}{0}\end{array}$ & $\overline{\tilde{o}}$ & $\hat{o}$ & $\underset{ٍ}{0}$ & $\frac{5}{0}$ & $\stackrel{8}{\circ}$ & $\underset{i}{\stackrel{\leftrightarrow}{i}}$ & ๙ి & $\stackrel{\circ}{i}$ & 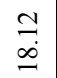 & $\stackrel{\text { กุ }}{0}$ & & $\stackrel{\circ}{\circ}$ & 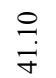 & $\frac{9}{0}$ & $\stackrel{\stackrel{m}{m}}{\longrightarrow}$ & $\stackrel{m}{0}$ & $\stackrel{n}{o}$ \\
\hline Glass ID & 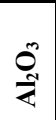 & ڤ్ & 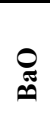 & 宓 & نَ & $\begin{array}{l}0 \\
0 \\
0\end{array}$ & రీ & $\stackrel{\wp}{\Xi}$ & on & $\begin{array}{l}0 \\
21\end{array}$ & 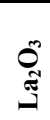 & : & $\sum_{\sum}^{\infty}$ & $\stackrel{\varrho}{E}$ & $\begin{array}{l}0 \\
\tilde{\tilde{Z}} \\
\ddot{Z}\end{array}$ & $\stackrel{?}{?}$ & $\stackrel{0}{n}^{n}$ & $\begin{array}{l}0 \\
\frac{1}{2}\end{array}$ & $\stackrel{0}{\infty}$ & क्ष & $\stackrel{\varrho}{\mathscr{O}}$ & 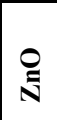 & : \\
\hline
\end{tabular}




\subsection{Glass Fabrication}

All glasses were prepared from reagent-grade metal oxides, carbonates, boric acid, and salts. ${ }^{12}$ For each glass, proper proportions of these constituents were thoroughly mixed in two separate $300 \mathrm{~g}$ batches and melted separately in $250 \mathrm{ml}$ platinum/gold crucibles at $1150^{\circ} \mathrm{C}$ for 1 hour in a high temperature furnace. ${ }^{12,13}$ After the isothermal hold, the glasses were poured onto stainless steel plates and allowed to air cool. Subsequently, the two pour patties for each glass composition were combined and melted again in $250 \mathrm{ml}$ platinum/gold crucibles at $1150^{\circ} \mathrm{C}$ for 1 hour in a high temperature furnace and similarly poured onto stainless steel and allowed to air cool. For the two higher alumina $\left(\mathrm{Fox}^{10}\right)$ glasses, the melt temperature was increased to $1200^{\circ} \mathrm{C}$ to facilitate melting. The glass pour patties were used as sample stock for cooling treatments and other analyses.

\subsection{Cooling Treatments}

Cooling treatments were developed using the conventional DWPF CCC schedule as the baseline. The DWPF CCC schedule was developed from data taken during scale glass melter (SGM) runs and is intended to simulate cooling that portion of glass in a canister which experiences the slowest cooling rate. Due to technology at the time, the historical laboratory CCC schedule was a stepped function profile that was created to best mimic the smooth profile cooling that the actual glass would experience. Therefore, the CCC approach currently used is inherently imperfect. The importance of this detail is understood by examining the recorded temperatures within canisters during SGM runs, as plotted in Figure 1. Most notably, after the maximum temperature of a centerline location in the canister is reached, the temperature decreases at approximately $0.3 \mathrm{~K} / \mathrm{min}$ between 800 and $400{ }^{\circ} \mathrm{C}^{14}$ which is the temperature range that nepheline is expected to form in HLW glasses. ${ }^{15,16}$ It is speculated that, given the temperature range in which nepheline is expected to form in HLW glass, a smooth cooling profile versus a stepped profile could significantly affect nepheline crystallization. Therefore, one goal of this research was to explore the effects of smooth cooling profiles versus stepped cooling profiles on nepheline crystallization.

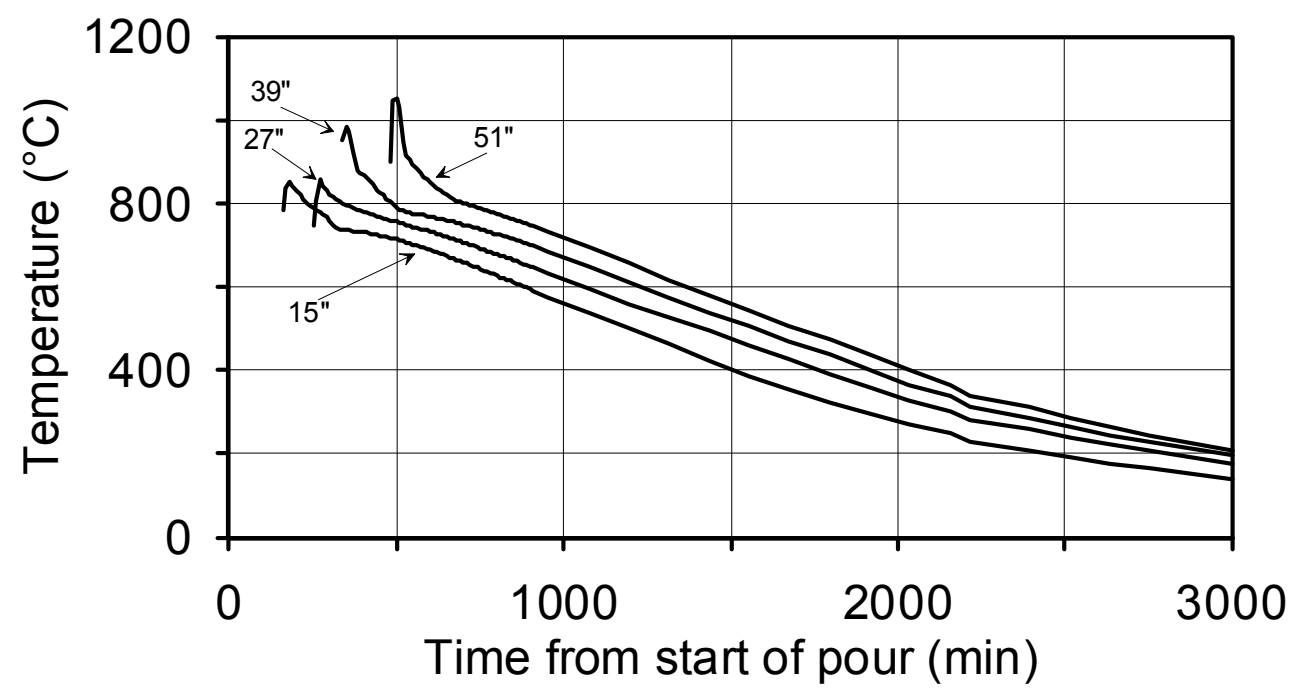

Figure 1. Temperature Along the Canister (B-49) Centerline During SGM-8. ${ }^{14}$ (Note That the Data at the Start of the Pour Has Been Removed for Clarity.)

Each glass was exposed to six cooling treatments. The treatments consisted of three stepped function profiles designated $\mathrm{CCC}-1, \mathrm{CCC}-3$, and $\mathrm{CCC}-5$ and three smooth function profiles 
designated CCCR-1, CCCR-3, and CCCR-5. The CCCR-\# designations represent smooth profiles designed to overlay the CCC-\# profiles. The CCC-3 treatment was the traditional DWPF CCC treatment and correspondingly the CCCR-3 represents a "smooth CCC." Likewise, CCC-1 and CCCR-1 correspond to stepped and smooth profiles respectively and represent a faster total cooling time compared to the CCC-3 or CCCR-3 schedules. Similarly, CCC-5 and CCCR-5 correspond to stepped and smooth profiles respectively and represent a slower total cooling time compared to the CCC-3 or CCCR-3 schedules.

The experimental cooling schedules were developed with the intent to reduce the variability between cooling treatments and to critically explore the effect of cooling through temperatures at which nepheline is expected to form. To accomplish this, temperatures between $800^{\circ} \mathrm{C}$ and $450^{\circ} \mathrm{C}$ were identified as the most critical based on Time-Temperature-Transformation (TTT) studies $^{15,16}$ and typical $\mathrm{T}_{\mathrm{g}}$ values of HLW glasses. In order to develop cooling schedules, SGM$8^{14}$ raw data from the $51^{\text {" }}$ thermocouple at the canister centerline (this data formed the basis for the conventional DWPF $\mathrm{CCC}^{17}$ ) was plotted and least squares linear regression fits to the data were used to identify critical rate changes between $800^{\circ} \mathrm{C}$ and $450^{\circ} \mathrm{C}$ as a function of cooling time. The results, shown in Figure 2, indicated that between $800-750{ }^{\circ} \mathrm{C}$ the cooling rate was $\sim 0.25 \mathrm{~K} / \mathrm{min}$ and between $750-350{ }^{\circ} \mathrm{C}$ the cooling rate was $\sim 0.3 \mathrm{~K} / \mathrm{min}$. The CCCR-3 cooling schedule was developed directly from this data and the fitting results.

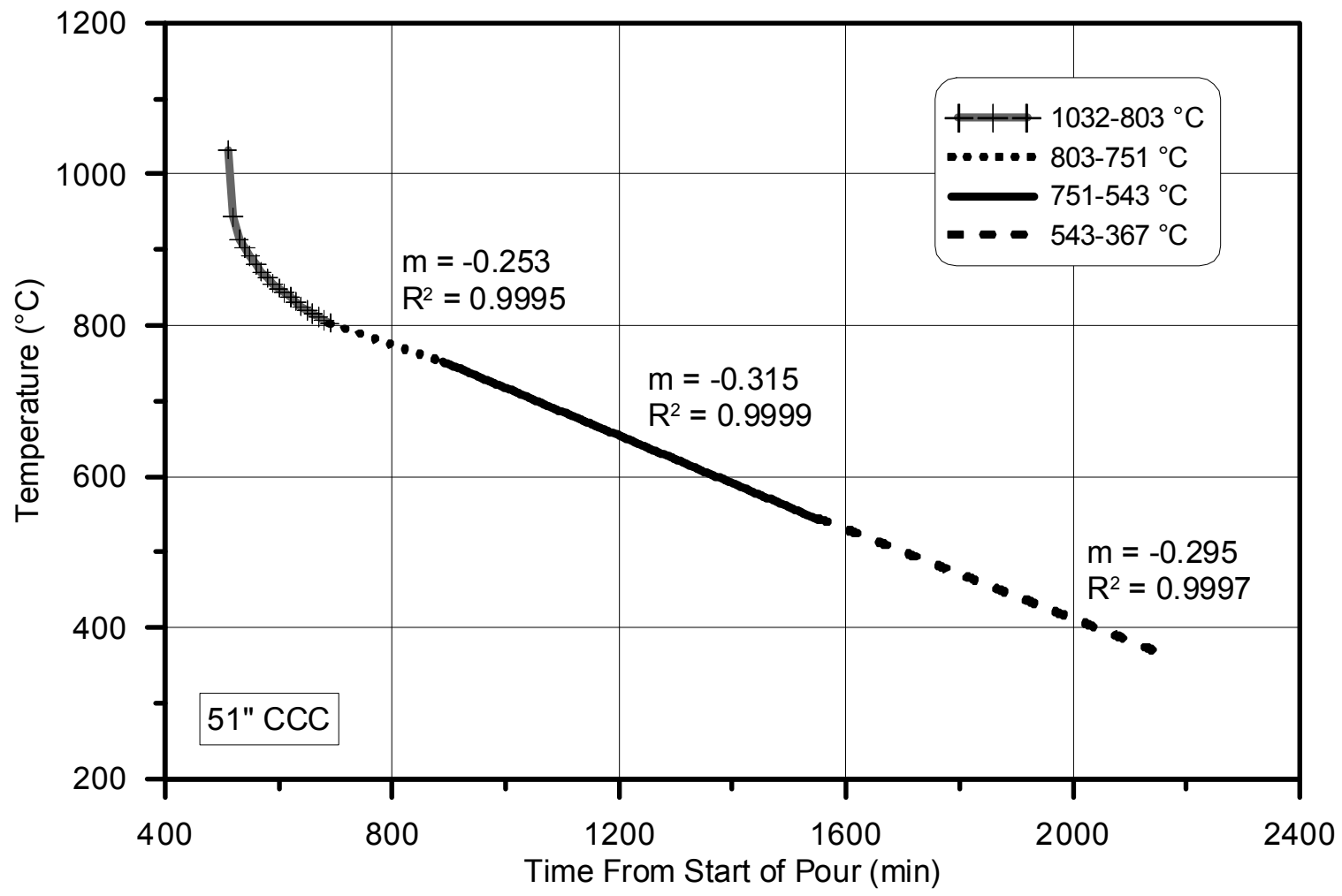

Figure 2. Plot of TC-4 Temperature Data From Canister B-49 14 During Pour and Cool Down Showing Fits to the Data Between $\sim 800^{\circ} \mathrm{C}-350^{\circ} \mathrm{C}$.

As stated previously, the temperature range of interest was $800-450{ }^{\circ} \mathrm{C}$ and therefore the CCCR-1, CCCR-5, and CCCR-3 schedules were identical for temperatures greater than $800^{\circ} \mathrm{C}$. 
Below $450^{\circ} \mathrm{C}$, the furnace power was shut off and the CCCR-1, CCCR-5, and CCCR-3 schedules all rapidly approached room temperature under natural heat loss processes. Three rates, 0.05 , 0.25 , and $0.45 \mathrm{~K} / \mathrm{min}$ were used between $800-750{ }^{\circ} \mathrm{C}$ for CCCR-1, CCCR-3 and CCCR-5 respectively and likewise, three rates, $0.1,0.3$, and $0.5 \mathrm{~K} / \mathrm{min}$ were used between $750-450{ }^{\circ} \mathrm{C}$ for CCCR-1, CCCR-3 and CCCR-5 respectively. The rates were selected for two main reasons: 1) to encompass potential cooling rates attainable by DWPF and 2) considered to encompass cooling rates that would either increase or decrease the likelihood of nepheline crystallization in most glasses.

The stepped cooling schedules were developed to correspond to the smooth cooling schedules and, as previously mentioned, the conventional DWPF CCC schedule was used as the baseline. In that schedule, there is an initial cooling rate $\sim 8 \mathrm{~K} / \mathrm{min}$ and then all subsequent cooling rates are $\sim 1 \mathrm{~K} / \mathrm{min}$. In developing the CCC-1 and CCC-5 schedules, the cooling rates were maintained and the dwell temperatures were kept identical to those in the CCC-3 (identical to conventional DWPF CCC) schedule. In order to generate cooling schedules that overlaid the smooth schedules, adjustments were necessarily made to the dwell times (not the cooling rates between dwell temperatures).

Plots of the target profiles are represented in Figure 3 and detailed set temperatures, dwell times, and ramp rates are listed in Table 2-3 and Table 2-4 for smoothed and stepped profiles respectively.

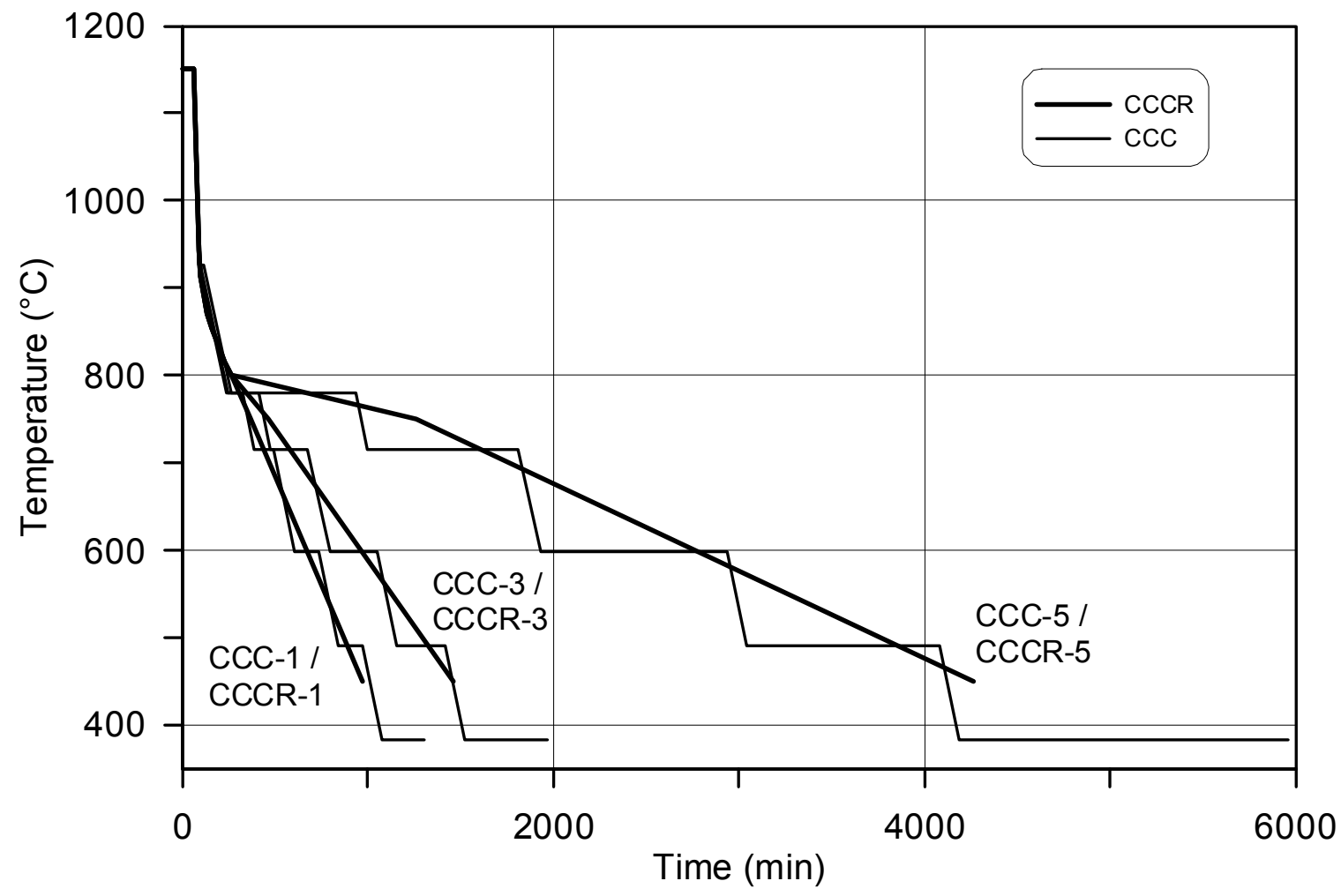

Figure 3. Target Cooling Profiles Used to Treat Glasses. 
Table 2-3. Target Setpoints and Cooling Rates Used for Smooth Cooling Schedules.

\begin{tabular}{|c|c|c|c|}
\hline & $\begin{array}{c}\text { Start Setpoint } \\
\left({ }^{\circ} \mathrm{C}\right)\end{array}$ & $\begin{array}{c}\text { End Setpoint } \\
\left({ }^{\circ} \mathrm{C}\right)\end{array}$ & Rate $(\mathrm{K} / \mathrm{min})$ \\
\hline & 1150 & 1150 & $\begin{array}{c}\text { Dwell for } 60 \\
\text { min. }\end{array}$ \\
\hline & 1150 & 943 & 8.88 \\
\hline & 943 & 914 & 2.91 \\
\hline & 914 & 871 & 1.09 \\
\hline & 871 & 854 & 0.78 \\
\hline & 854 & 815 & 0.58 \\
\hline & 815 & 800 & 0.40 \\
\hline \multirow[t]{3}{*}{ CCCR-5 } & $\rightarrow 800$ & 750 & 0.45 \\
\hline & 750 & 450 & 0.5 \\
\hline & 450 & 0 & $\infty$ \\
\hline \multirow[t]{3}{*}{ CCCR-3 } & $\rightarrow 800$ & 750 & 0.25 \\
\hline & 750 & 450 & 0.3 \\
\hline & 450 & 0 & $\infty$ \\
\hline \multirow[t]{3}{*}{ CCCR-1 } & $\rightarrow 800$ & 750 & 0.05 \\
\hline & 750 & 450 & 0.1 \\
\hline & 450 & 0 & $\infty$ \\
\hline
\end{tabular}

* Note that temperatures indicated in the tables are ideal. In practice, the furnace setpoints were adjusted to account for inaccuracies in furnace temperature controls. 
Table 2-4. Target Setpoints, Cooling Rates, and Dwell Times Used for Stepped Cooling Schedules.

\begin{tabular}{|c|c|c|c|c|c|c|c|c|c|c|c|}
\hline \multicolumn{4}{|c|}{ CCC-5 } & \multicolumn{4}{|c|}{ CCC-3 } & \multicolumn{4}{|c|}{ CCC-1 } \\
\hline \multirow{2}{*}{$\begin{array}{c}\text { Start Setpoint } \\
\left({ }^{\circ} \mathbf{C}\right) \\
1150\end{array}$} & \multirow{2}{*}{$\begin{array}{c}\text { End Setpoint } \\
\left({ }^{\circ} \mathrm{C}\right)\end{array}$} & \multicolumn{2}{|c|}{$\begin{array}{c}\text { Rate }(\mathrm{K} / \mathrm{min}) / \\
\text { Dwell (min) }\end{array}$} & \multirow{2}{*}{$\begin{array}{c}\begin{array}{c}\text { Start Setpoint } \\
\left({ }^{\circ} \mathrm{C}\right)\end{array} \\
1150\end{array}$} & \multirow{2}{*}{$\begin{array}{c}\text { End Setpoint } \\
\left({ }^{\circ} \mathrm{C}\right)\end{array}$} & \multicolumn{2}{|c|}{$\begin{array}{l}\text { Rate (K/min) / } \\
\text { Dwell (min) }\end{array}$} & \multirow{2}{*}{$\begin{array}{c}\begin{array}{c}\text { Start Setpoint } \\
\left({ }^{\circ} \mathrm{C}\right)\end{array} \\
1150\end{array}$} & \multirow{2}{*}{$\begin{array}{c}\text { End Setpoint } \\
\left({ }^{\circ} \mathrm{C}\right)\end{array}$} & \multicolumn{2}{|c|}{$\begin{array}{c}\text { Rate }(\mathrm{K} / \mathrm{min}) \\
\text { Dwell (min) }\end{array}$} \\
\hline & & Dwell & 60 & & & Dwell & 60 & & & Dwell & 60 \\
\hline 1150 & 926 & Ramp & 8 & 1150 & 926 & Ramp & 8 & 1150 & 926 & Ramp & 8 \\
\hline 926 & 926 & Dwell & 3 & 926 & 926 & Dwell & 6 & 926 & 926 & Dwell & 24 \\
\hline 926 & 779 & Ramp & 1 & 926 & 779 & Ramp & 1 & 926 & 779 & Ramp & 1 \\
\hline 779 & 779 & Dwell & 84 & 779 & 779 & Dwell & 168 & 779 & 779 & Dwell & 672 \\
\hline 779 & 715 & Ramp & 1 & 779 & 715 & Ramp & 1 & 779 & 715 & Ramp & 1 \\
\hline 715 & 715 & Dwell & 102 & 715 & 715 & Dwell & 204 & 715 & 715 & Dwell & 816 \\
\hline 715 & 598 & Ramp & 1 & 715 & 598 & Ramp & 1 & 715 & 598 & Ramp & 1 \\
\hline 598 & 598 & Dwell & 126 & 598 & 598 & Dwell & 252 & 598 & 598 & Dwell & 1008 \\
\hline 598 & 490 & Ramp & 1 & 598 & 490 & Ramp & 1 & 598 & 490 & Ramp & 1 \\
\hline 490 & 490 & Dwell & 129 & 490 & 490 & Dwell & 258 & 490 & 490 & Dwell & 1032 \\
\hline 490 & 382 & Ramp & 1 & 490 & 382 & Ramp & 1 & 490 & 382 & Ramp & 1 \\
\hline 382 & 382 & Dwell & 222 & 382 & 382 & Dwell & 444 & 382 & 382 & Dwell & 1776 \\
\hline 382 & 70 & Ramp & 1 & 382 & 70 & Ramp & 1 & 382 & 70 & Ramp & 1 \\
\hline 70 & 0 & Ramp & $\infty$ & 70 & 0 & Ramp & $\infty$ & 70 & 0 & Ramp & $\infty$ \\
\hline
\end{tabular}


For each heat treatment, approximately $25 \mathrm{~g}$ (to mimic current CCC methods) of quenched glass was placed in a platinum/gold alloy crucible, loaded into a laboratory furnace at $1150^{\circ} \mathrm{C}$, and held for one hour before initiating the desired cooling schedule. All cooling treatments were carried out in laboratory furnaces equipped with independent thermocouples inserted into the center of the furnace's heating zone where the samples were located. The temperatures from the independent thermocouples were recorded to confirm the cooling schedule. Due to availability, eight $30 \mathrm{ml}$ and eight $50 \mathrm{ml}$ crucibles were used for heat treatments. Crucible size and glass compositions were paired randomly. However, once paired, the crucible size remained the same for all treatments for each glass, while the physical crucibles used were interchanged randomly to avoid crucible biases. After treatment, the glass was removed from the crucible and resembled a glass puck as shown in Figure 4.

\subsection{Analyses}

\subsubsection{Chemical Composition}

A representative sample from each quenched glass was submitted to the SRNL Process Science Analytical Laboratory (PSAL) for chemical analysis to confirm that the as-fabricated glasses met the target compositions. Two digestion methods, sodium peroxide fusion (PF) and lithiummetaborate fusion (LM), were used to prepare samples for cation measurements. Each glass was prepared in duplicate for each of the dissolution techniques. All of the prepared samples were analyzed twice for each element of interest by Inductively Coupled Plasma - Atomic Emission Spectroscopy (ICP-AES), with the instrumentation being re-calibrated between the duplicate analyses. Glass standards were also intermittently measured to ensure the performance of the ICP-AES instrument over the course of the analyses. The measured cation concentrations were converted to their respective oxide listed in Table 2-2 to obtain a wt $\%$ of each component oxide.

\subsubsection{X-ray Diffraction}

Quenched and heat treated samples were measured using x-ray diffraction (XRD) to quantify any crystallization. Samples from all glasses were submitted to SRNL Analytical Development (AD) for XRD analysis. AD initially ground samples in an automatic Spex mill for 4 minutes. Subsequently, the powders were hand ground in agate with alcohol and mounted to a glass slide using a collidion/Amyl Acetate solution for XRD. The measurement conditions provided a $0.5 \mathrm{wt} \%$ detection limit, meaning that if a crystal phase was present at this concentration (or greater), the type of crystal(s) (or phase) could be identified. It follows that if a characteristically broad hump(s) is measured, then the sample is considered x-ray amorphous under the measurement conditions.

Preliminary studies indicated that sampling location on glasses exposed to the DWPF CCC schedule affected the XRD results. It was hypothesized that the interior of treated glasses would be microstructurally different than the exterior which, is exposed to the atmosphere and crucible wall. In order to ensure direct comparisons among glasses, two types of samples were submitted for XRD analysis from treated glasses designated as 'center-slice' and 'interior'. Center-slice and interior samples were prepared by sectioning the treated glasses with a diamond saw to obtain portions as shown in Figure 4. Samples that were submitted to XRD designated as 'interior' were sectioned so as to obtain only that portion in the center of the glass that appeared homogeneous. To ensure that enough sample was available for XRD analysis from glasses that exhibited a substantially large amount of crystal penetration into the center, additional sample was obtained 
from similar areas in the glass not previously sectioned. Additionally, one representative (no prepreparation) sample from each quenched glass was submitted for XRD analysis.

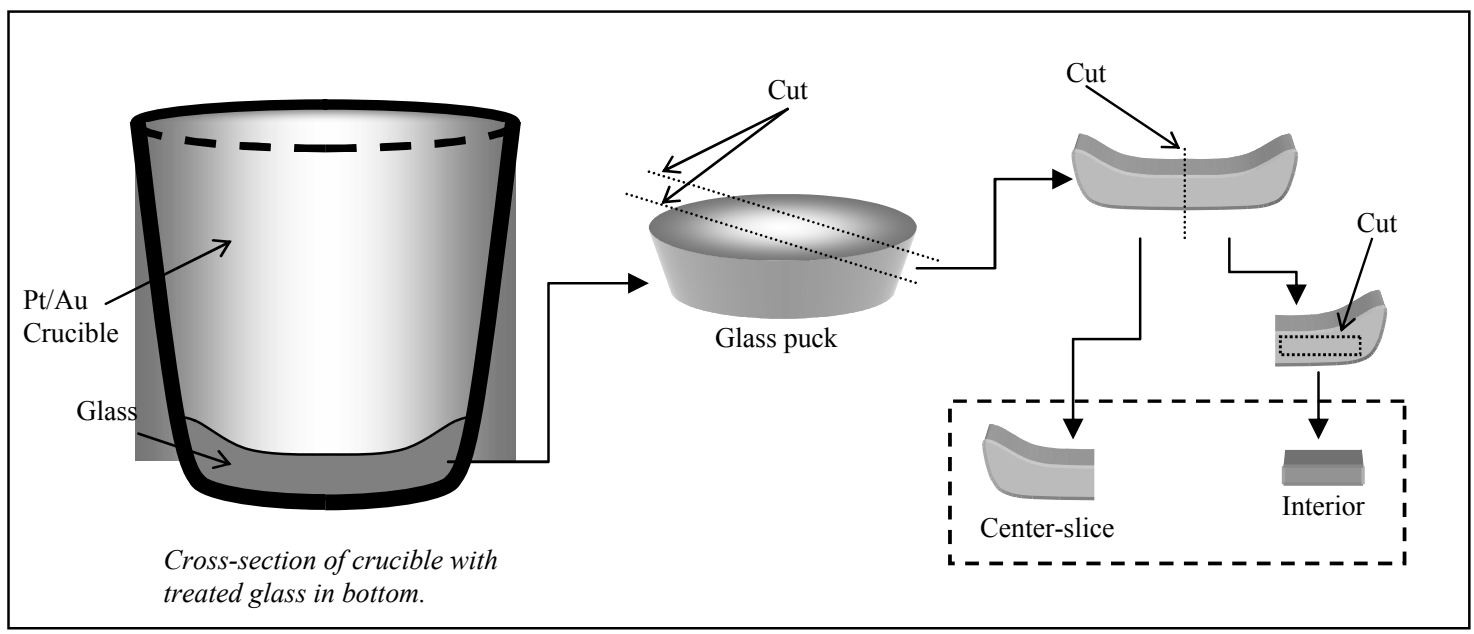

Figure 4. Process Steps Involved in Preparing 'Center-Slice' and 'Interior' Samples for XRD Analysis.

\subsection{Results and Discussion}

\subsection{Chemical Composition}

Measured glass compositions were generally consistent with target compositions with the following exceptions: The measured amount of boron in glass NP2-10 was higher than expected. The source of this difference is unknown. For the high alumina glasses, 121506-07, 121506-08, and HWI-ALS-03, several of the cation concentrations deviated from expected, most notably, the aluminium concentration. These differences are thought to be due to the refractory nature of these glasses. Additionally, the measured silicon concentration was biased high for several samples although, this is not uncommon. Target and measured chemical composition for each glass are listed in Table 3-1. 
Table 3-1. Target and Measured Chemical Composition of Glasses

\begin{tabular}{|c|c|c|c|c|c|c|c|c|c|c|c|c|c|c|c|c|c|c|c|c|c|c|c|c|}
\hline & & $\mathrm{Al}_{2} \mathrm{O}_{3}$ & $\mathrm{~B}_{2} \mathrm{O}_{3}$ & $\mathrm{BaO}$ & $\mathrm{Bi}_{2} \mathrm{O}_{3}$ & $\mathrm{CaO}$ & $\mathrm{Ce}_{2} \mathrm{O}_{3}$ & $\mathrm{Cr}_{2} \mathrm{O}_{3}$ & $\mathrm{CuO}$ & $\mathrm{Fe}_{2} \mathrm{O}_{3}$ & $\mathrm{~K}_{2} \mathrm{O}$ & $\mathrm{La}_{2} \mathrm{O}_{3}$ & $\mathrm{Li}_{2} \mathrm{O}$ & $\mathrm{MgO}$ & $\mathrm{MnO}$ & $\mathrm{Na}_{2} \mathrm{O}$ & $\mathrm{NiO}$ & $\mathrm{P}_{2} \mathrm{O}_{5}$ & $\mathrm{PbO}$ & $\mathrm{SiO}_{2}$ & $\begin{array}{c}\mathrm{SO}_{3} / \\
\mathrm{SO}_{4}\end{array}$ & $\mathrm{TiO}_{2}$ & $\mathrm{ZnO}$ & $\mathrm{ZrO}_{2}$ \\
\hline \multirow{2}{*}{ NP2-11 } & Target & 18.00 & 14.00 & & & & & 0.20 & & 5.85 & & & 6.97 & 0.00 & 4.65 & 15.33 & 0.00 & & & 35.00 & & & & \\
\hline & Measured & 17.55 & 14.59 & & & & & 0.18 & & 5.81 & & & 6.73 & 0.01 & 5.54 & 14.99 & 0.03 & & & 35.57 & & & & \\
\hline \multirow{2}{*}{ NP2-15 } & Target & 18.00 & 14.00 & 0.00 & & & & & & 5.00 & & & 4.00 & 1.50 & 0.50 & 18.00 & 2.50 & & & 35.00 & & 1.50 & 0.00 & \\
\hline & Measured & 18.20 & 14.55 & 0.01 & & & & & & 5.86 & & & 3.93 & 1.37 & 0.59 & 17.48 & 2.25 & & & 35.16 & & 1.43 & 0.02 & \\
\hline \multirow{2}{*}{ NP2-10 } & Target & 10.65 & 10.17 & & & 0.95 & & & & 13.64 & & & 5.16 & 0.68 & 0.50 & 13.43 & 0.00 & & & 44.82 & & & & \\
\hline & Measured & 10.67 & 12.25 & & & 0.96 & & & & 13.79 & & & 5.76 & 0.64 & 0.59 & 13.03 & 0.04 & & & 45.28 & & & & \\
\hline \multirow{2}{*}{ NP2-08 } & Target & 6.97 & 13.32 & & & 4.00 & & & & 5.00 & & 0.00 & 7.00 & 0.00 & 3.62 & 15.38 & 0.00 & & & 42.70 & & 2.00 & & \\
\hline & Measured & 7.20 & 14.75 & & & 4.28 & & & & 5.18 & & 0.01 & 6.94 & 0.02 & 4.27 & 14.99 & 0.03 & & & 42.95 & & 1.94 & & \\
\hline \multirow{2}{*}{ NP2-25 } & Target & 12.33 & 8.36 & & & 1.58 & & 0.09 & & 9.87 & & & 5.33 & 0.55 & 2.48 & 15.26 & 0.69 & & & 42.16 & & 1.30 & & \\
\hline & Measured & 12.46 & 9.14 & & & 1.69 & & 0.09 & & 9.95 & & & 5.27 & 0.52 & 2.93 & 14.85 & 0.65 & & & 42.19 & & 1.25 & & \\
\hline \multirow{2}{*}{ NP2-02 } & Target & 7.22 & 14.00 & & & & & 0.20 & & 5.00 & & & 4.00 & 0.00 & 0.62 & 18.00 & 0.00 & & & 48.96 & & 2.00 & & \\
\hline & Measured & 7.37 & 15.23 & & & & & 0.19 & & 5.11 & & & 3.91 & 0.01 & 0.74 & 18.09 & 0.03 & & & 49.80 & & 1.95 & & \\
\hline \multirow{2}{*}{ NP2-22 } & Target & 13.97 & 4.50 & & & 0.02 & & 0.02 & & 7.09 & & & 4.87 & 0.00 & 1.58 & 18.00 & 0.20 & & & 47.75 & & 2.00 & & \\
\hline & Measured & 14.20 & 5.22 & & & $<0.1$ & & 0.03 & & 7.46 & & & 4.84 & 0.02 & 1.88 & 18.02 & 0.24 & & & 48.36 & & 1.97 & & \\
\hline \multirow{2}{*}{ NP2-23 } & Target & 12.28 & 4.50 & & & 4.00 & & 0.20 & & 7.22 & & & 4.00 & 1.50 & 1.19 & 18.00 & 0.17 & & & 44.94 & & 2.00 & & \\
\hline & Measured & 12.57 & 4.94 & & & 4.34 & & 0.17 & & 7.35 & & & 3.99 & 1.36 & 1.41 & 17.55 & 0.18 & & & 45.48 & & 1.95 & & \\
\hline \multirow{2}{*}{$121506-07$} & Target & 26.64 & 18.00 & 0.06 & 1.19 & 14.00 & & 0.54 & & 6.15 & 3.70 & 0.00 & & 0.12 & & 5.00 & 0.42 & 1.10 & 0.43 & 21.21 & 0.21 & 0.01 & 0.09 & 0.41 \\
\hline & Measured & 27.84 & 18.08 & 0.03 & 1.08 & 15.00 & & 0.32 & & 5.75 & 3.94 & 0.02 & & 0.12 & & 4.83 & 0.38 & 0.84 & 0.41 & 21.83 & 0.21 & $<0.1$ & 0.11 & 0.27 \\
\hline \multirow{2}{*}{$121506-08$} & Target & 26.63 & 15.21 & 0.06 & 1.27 & 6.50 & & 0.58 & & 6.55 & 0.16 & 0.00 & 4.04 & 0.13 & & 8.98 & 0.44 & 1.17 & 0.45 & 26.29 & 0.22 & 0.01 & 0.09 & 0.44 \\
\hline & Measured & 27.78 & 15.81 & 0.06 & 1.19 & 7.14 & & 0.38 & & 6.18 & 0.00 & 0.01 & 3.92 & 0.13 & & 8.61 & 0.38 & 1.00 & 0.42 & 26.86 & 0.22 & $<0.1$ & 0.09 & 0.29 \\
\hline \multirow{2}{*}{ HWI-ALS-03 } & Target & 16.56 & 16.64 & 0.09 & & 1.37 & 0.09 & 0.16 & 0.04 & 9.03 & 0.10 & 0.05 & 3.64 & 0.18 & 0.86 & 13.45 & 0.15 & & 0.03 & 35.71 & 0.07 & 1.49 & 0.04 & 0.23 \\
\hline & Measured & 17.34 & 17.15 & 0.09 & & 1.51 & $<0.01$ & 0.14 & $<0.1$ & 8.97 & $<0.1$ & 0.05 & 3.50 & 0.18 & 1.02 & 12.85 & 0.16 & & $<0.1$ & 36.74 & $<0.03$ & 1.43 & 0.05 & 0.23 \\
\hline \multirow{2}{*}{ EM-N1-19 } & Target & 10.66 & 4.08 & 0.12 & & 1.61 & 0.15 & 0.20 & 0.07 & 17.15 & 0.16 & 0.08 & 2.04 & 0.19 & 1.97 & 18.16 & 0.24 & & 0.09 & 41.13 & 0.18 & 1.26 & 0.12 & 0.33 \\
\hline & Measured & 11.25 & 5.57 & 0.11 & & 1.79 & 0.16 & 0.18 & $<0.1$ & 16.73 & 0.17 & 0.08 & 2.07 & 0.20 & 2.39 & 18.56 & 0.24 & & $<0.1$ & 43.02 & 0.18 & 1.18 & 0.12 & 0.33 \\
\hline \multirow{2}{*}{ EM-N1-24 } & Target & 9.35 & 4.56 & 0.10 & & 1.42 & 0.13 & 0.17 & 0.06 & 13.26 & 0.14 & 0.07 & 2.28 & 0.17 & 1.73 & 20.13 & 0.21 & & 0.08 & 44.47 & 0.16 & 1.11 & 0.10 & 0.29 \\
\hline & Measured & 9.75 & 5.23 & 0.10 & & 1.36 & 0.14 & 0.17 & $<0.1$ & 13.05 & 0.15 & 0.07 & 2.29 & 0.17 & 2.08 & 20.12 & 0.22 & & $<0.1$ & 45.52 & 0.12 & 1.02 & 0.10 & 0.29 \\
\hline \multirow{2}{*}{ EM-N1-25 } & Target & 10.00 & 4.32 & 0.11 & & 1.52 & 0.14 & 0.19 & 0.07 & 14.18 & 0.15 & 0.08 & 2.70 & 0.18 & 1.85 & 17.18 & 0.22 & & 0.08 & 45.24 & 0.17 & 1.18 & 0.11 & 0.31 \\
\hline & Measured & 10.18 & 4.85 & 0.11 & & 1.65 & 0.15 & 0.17 & $<0.1$ & 13.75 & 0.16 & 0.07 & 2.72 & 0.18 & 2.21 & 17.21 & 0.23 & & $<0.1$ & 46.25 & 0.17 & 1.11 & 0.11 & 0.31 \\
\hline \multirow{2}{*}{ EM-N1-26 } & Target & 10.66 & 4.08 & 0.12 & & 1.61 & 0.15 & 0.20 & 0.07 & 15.11 & 0.16 & 0.08 & 2.55 & 0.19 & 1.97 & 17.65 & 0.24 & & 0.09 & 43.17 & 0.18 & 1.26 & 0.12 & 0.33 \\
\hline & Measured & 11.08 & 4.65 & 0.12 & & 1.77 & 0.16 & 0.19 & $<0.1$ & 14.73 & 0.17 & 0.08 & 2.59 & 0.19 & 2.36 & 18.16 & 0.24 & & $<0.1$ & 44.37 & 0.17 & 1.21 & 0.12 & 0.33 \\
\hline \multirow{2}{*}{ EM-N1-27 } & Target & 11.31 & 3.84 & 0.13 & & 1.71 & 0.16 & 0.21 & 0.07 & 16.03 & 0.17 & 0.09 & 2.40 & 0.20 & 2.09 & 18.12 & 0.25 & & 0.09 & 41.10 & 0.19 & 1.34 & 0.13 & 0.35 \\
\hline & Measured & 11.50 & 4.11 & 0.12 & & 1.83 & 0.17 & 0.33 & $<0.1$ & 16.16 & 0.18 & 0.08 & 2.33 & 0.20 & 2.44 & 18.63 & 0.25 & & $<0.1$ & 41.10 & 0.17 & 1.25 & 0.12 & 0.34 \\
\hline
\end{tabular}




\subsection{Smooth versus Stepped Cooling}

Before the cooling treatments were performed, a test glass was run according to a revised smooth CCC (CCCR-3) schedule to ensure the glass and furnace temperatures were similar and to ensure that the glass temperature would not lag behind the furnace temperature during cooling. To do this, a thermocouple probe was inserted just above the glass melt pool and an additional bare-wire thermocouple was submerged in the glass melt pool. Figure 5 is a plot showing the recorded temperatures for the glass and furnace. The CCC temperature at the 51" mark of canister B-49 during SGM-8 is shown for comparison purposes. ${ }^{14}$ Shown also in the plot is the calculated temperature difference between the glass and the furnace. Although the glass cooled more rapidly compared to the furnace initially, the glass and furnace temperature difference stabilized and remained relatively constant $\left( \pm \sim 2^{\circ} \mathrm{C}\right)$ from $\sim 800^{\circ} \mathrm{C}$ until the furnace was turned off below $\mathrm{T}_{\mathrm{g}}$ at which point, the glass again cooled more rapidly than the furnace. This behavior was presumably due to the heat transfer from the glass to the furnace's atmosphere and the positioning of the furnace thermocouple directly above the glass melt.

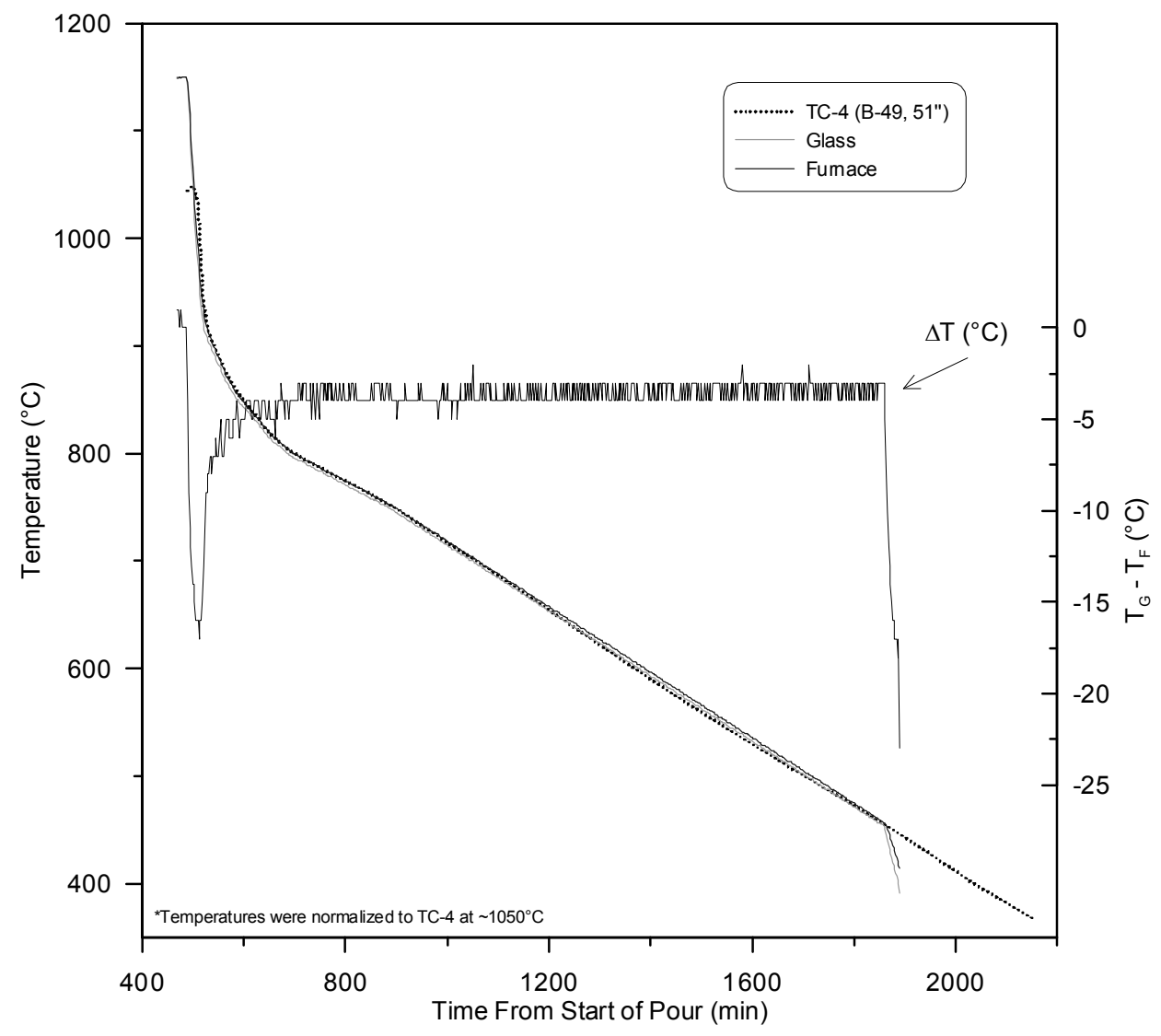

Figure 5. Recorded Temperatures of the Glass and Furnace During Laboratory Smooth CCC (CCCR-3) Compared to Canister (B-49) Filling Thermocouple Data ${ }^{14}$. Also Shown is the Temperature Difference between the Actual Glass and the Furnace. A Negative Number indicates the Glass is Colder Compared to the Furnace.

The results of this study indicate that glasses exposed to a stepped CCC schedule result in different quantities of nepheline and other crystal phases compared to those same glasses exposed to its counterpart smooth CCC schedule. 
Table 3-2 and Table 3-3 summarize the differences in measured crystal phase for nepheline and non-nepheline phases respectively. The complete quantitative data set is listed in Table 3-5.

At cooling times equal to the $\mathrm{CCC}$ schedule, there appeared to be little difference $(<1 \mathrm{wt} . \%)$ in the amount of measured nepheline for most glasses; however, there was two glasses, NP2-23 and NP2-11 in which a difference of $\sim 5 \mathrm{wt} \%$ nepheline was calculated. At shorter (relative to CCC) total cooling times, the stepped profile appeared to cause more nepheline to precipitate in the glasses compared to smooth profiles. For increased (relative to CCC) total cooling times, the stepped profile appeared to cause less nepheline to precipitate in the glasses compared to the smooth profile.

Similar trends were observed for non-nepheline phases. Overall, the difference in measured nonnepheline crystallization after smooth cooling versus stepped cooling appeared to increase with increasing total cooling time albeit at a much reduced rate compared to nepheline. At shorter total cooling times, smooth cooling profiles precipitated less non-nepheline phase compared to stepped cooling, whereas the reverse was observed for longer total cooling times in which more non-nepheline phase was measured in glasses exposed to smooth cooling profiles compared to stepped cooling profiles.

The difference in stepped versus smooth profile cooling is thought to be due to the crystal kinetics taking place in the glass during cooling and as such, further discussion of the observed trends in smooth versus stepped cooling will be discussed in the sections that follow.

Table 3-2. Calculated Nepheline Phase Concentrations: Smooth Cooling Minus Stepped Cooling.

\begin{tabular}{lccc}
\hline \multirow{2}{*}{ Sample } & \multicolumn{3}{c}{$\Delta=$ CCCR-\# - CCC-\# (wt. \%) } \\
\cline { 2 - 4 } & $\mathbf{1}$ (slow) & $\mathbf{3}$ (CCC) & $\mathbf{5}$ (Fast) \\
\hline NP2-02 & - & - & - \\
EM-N1-24 & - & - & - \\
EM-N1-25 & - & - & - \\
NP2-10 & $\mathbf{0 . 5}$ & - & - \\
NP2-08 & - & - & - \\
NP2-25 & $\mathbf{1 . 1}$ & - & - \\
NP2-22 & $\mathbf{0 . 7}$ & $\mathbf{0 . 5}$ & - \\
NP2-23 & $\mathbf{3 . 6}$ & $\mathbf{5 . 6}$ & - \\
EM-N1-26 & $\mathbf{4 . 4}$ & $\mathbf{0 . 0}$ & - \\
EM-N1-19 & $\mathbf{7 . 5}$ & $\mathbf{0 . 6}$ & $\mathbf{- 1 . 0}$ \\
EM-N1-27 & $\mathbf{8 . 8}$ & $\mathbf{- 0 . 5}$ & $\mathbf{- 1 . 2}$ \\
NP2-15 & $\mathbf{8 . 6}$ & $\mathbf{0 . 7}$ & $\mathbf{- 2 . 6}$ \\
NP2-11 & $\mathbf{2 . 4}$ & $\mathbf{- 5 . 1}$ & $\mathbf{- 0 . 8}$ \\
HWI-ALS-03 & - & - & - \\
121506-07 & - & - & - \\
121506-08 & $\mathbf{1 . 8}$ & - & - \\
\hline *Quantitative data from Table 3-5 used to generate this table. \\
**Values in Table 3-5that were “<0.5” taken to be “0.5”. \\
\end{tabular}

Table 3-3. Calculated Non-Nepheline Phase Concentrations: Smooth Cooling Minus Stepped Cooling.

\begin{tabular}{lccc}
\hline \multirow{2}{*}{ Sample } & \multicolumn{3}{c}{$\Delta=\mathbf{C C C R}-\#-\mathbf{C C C}$ \# (wt. \%) } \\
\cline { 2 - 4 } & $\mathbf{1}$ (slow) & $\mathbf{3}$ (CCC) & $\mathbf{5}$ (Fast) \\
\hline NP2-02 & - & - & - \\
EM-N1-24 & - & - & - \\
EM-N1-25 & - & - & - \\
NP2-10 & - & - & - \\
NP2-08 & $\mathbf{1 . 2}$ & - & - \\
NP2-25 & $\mathbf{- 0 . 5}$ & - & - \\
NP2-22 & $\mathbf{- 0 . 5}$ & - & - \\
NP2-23 & - & - & - \\
EM-N1-26 & $\mathbf{1 . 0}$ & $\mathbf{0 . 0}$ & - \\
EM-N1-19 & $\mathbf{1 . 1}$ & $-\mathbf{0 . 7}$ & $\mathbf{0 . 4}$ \\
EM-N1-27 & $\mathbf{1 . 0}$ & $\mathbf{- 0 . 8}$ & $\mathbf{- 0 . 7}$ \\
NP2-15 & $\mathbf{0 . 5}$ & $\mathbf{0 . 3}$ & $\mathbf{- 0 . 3}$ \\
NP2-11 & $\mathbf{- 0 . 5}$ & - & - \\
HWI-ALS-03 & $\mathbf{0 . 7}$ & $\mathbf{0 . 9}$ & $\mathbf{- 0 . 5}$ \\
121506-07 & $\mathbf{0 . 1}$ & $\mathbf{- 0 . 4}$ & $\mathbf{- 0 . 2}$ \\
121506-08 & $\mathbf{- 0 . 5}$ & $\mathbf{0}$ & $\mathbf{- 0 . 7}$ \\
\hline *Quantitative data from Table 3-5 used to generate this table. \\
**Values in Table 3-5that were “<0.5" taken to be “0.5”.
\end{tabular}

\subsection{Crystallization}

Table 3-4 summarizes the qualitative XRD results for center-slice and quenched samples of the test glasses. Nepheline was not measured in any of the quenched glasses however, glasses NP2- 
15 and 121506-08 contained equal to, or below, the quantification limit of $\operatorname{LiNi}_{0.5} \operatorname{Ti}_{0.5} \mathrm{O}_{2}$ and $\mathrm{Fe}_{2.3} \mathrm{Si}_{0.7} \mathrm{O}_{4}$, respectively. Otherwise, the quenched glasses were amorphous. Additionally, glasses exposed to the CCC-3 schedule (traditional DWPF stepped CCC profile) were generally consistent with previous studies with the following exceptions: In this study NP2-15 exhibited nepheline and trevorite whereas in the previous study only nepheline was measured and, NP2-22 was amorphous whereas in the previous study nepheline was measured. This latter result is consistent with PNNL's assessment of the original NP2-22 study glass. ${ }^{18}$ The compositions of these glasses were not adjusted prior to batching and therefore unlikely the source of the differences. It is thought that the relative concentrations of phases and the XRD detection limit are the sources of these differences; however, quantitative analysis was not performed in previous studies and therefore the apparent differences are difficult to discern.

Table 3-5 summarizes the quantitative XRD results for center-slice and quenched samples of the test glasses, respectively. The results in Table 3-4 and Table 3-5 have been organized according to the extent of nepheline crystallization in the study glasses and as such, the study glasses have been categorized into groups based on measured crystallization and will be discussed in turn.

Table 3-4. Qualitative XRD Results for Quenched and Center-Slice Samples.

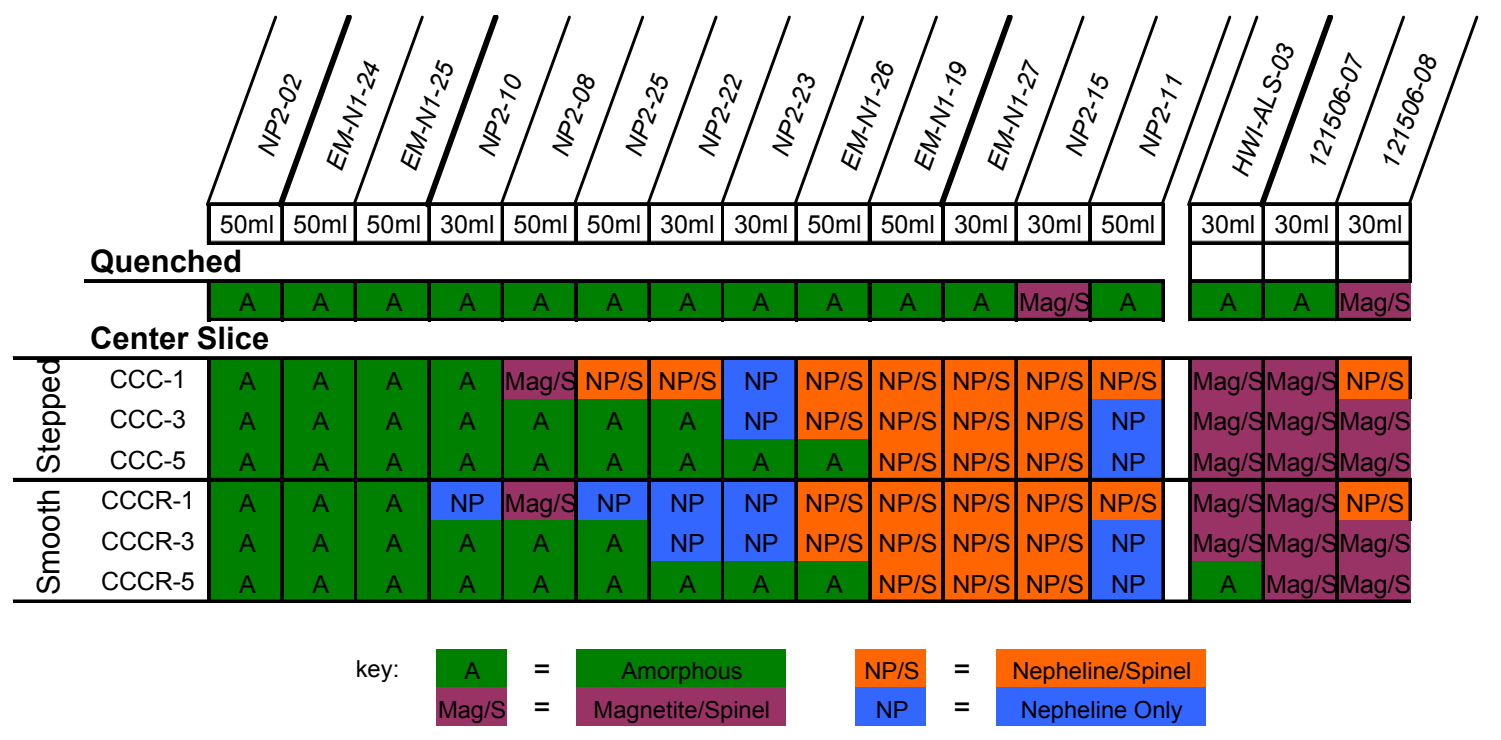


Table 3-5. Quantitative* XRD Results for Quenched and Center-Slice Samples.

\begin{tabular}{|c|c|c|c|c|c|c|c|c|c|c|c|c|c|c|c|}
\hline \multirow{4}{*}{$\begin{array}{l}\text { Sample } \\
\text { NP2-02 }\end{array}$} & & & \multicolumn{6}{|c|}{ Nepheline (wt \%) } & \multicolumn{6}{|c|}{ Secondary Phase (wt\%) } & \multirow{3}{*}{ Phase } \\
\hline & \multicolumn{2}{|c|}{ Quenched } & \multicolumn{3}{|c|}{ Stepped } & \multicolumn{3}{|c|}{ Smooth } & \multicolumn{3}{|c|}{ Stepped } & \multicolumn{3}{|c|}{ Smooth } & \\
\hline & wt $\%$ & Phase & CCC-1 & CCC-3 & $\mathrm{CCC}-5$ & CCCR-1 & CCCR-3 & CCR-5 & CCC-1 & CCC-3 & CCC-5 & CCCR- & SCCR- & CCR-5 & \\
\hline & & & & & & & & & & & & & & & \\
\hline EM-N1-24 & & & & & & & & & & & & & & & \\
\hline EM-N1-25 & & & & & & & & & & & & & & & \\
\hline NP2-10 & & & & & & $<0.5$ & & & & & & & & & \\
\hline NP2-08 & & & & & & & & & $<0.5$ & & & 1.7 & & & $\begin{array}{c}\mathrm{Li}_{2} \mathrm{SiO}_{3} \\
\text { (Lithium Silicate) }\end{array}$ \\
\hline NP2-25 & & & 2.5 & & & 3.6 & & & 0.5 & & & & & & $\begin{array}{c}\mathrm{NiFe}_{2} \mathrm{O}_{4} \\
\text { (Trevorite) } \\
\end{array}$ \\
\hline NP2-22 & & & 3.2 & & & 3.9 & $<0.5$ & & $<0.5$ & & & & & & $\begin{array}{c}\mathrm{Li}_{2} \mathrm{SiO}_{3} \\
\text { (Lithium Silicate) }\end{array}$ \\
\hline NP2-23 & & & 7.7 & $<0.5$ & & 11.3 & 5.6 & & & & & & & & \\
\hline EM-N1-26 & & & 7.8 & $<0.5$ & & 12.2 & $<0.5$ & & 1.6 & $<0.5$ & & 2.6 & $<0.5$ & & $\begin{array}{l}\mathrm{Fe}^{2+} \mathrm{Fe}^{3+}{ }_{2} \mathrm{O}_{4} \\
\text { (Magnetite) }\end{array}$ \\
\hline EM-N1-19 & & & 12 & 5.6 & 3.9 & 19.5 & 6.2 & 2.9 & 2.4 & 2 & 0.8 & 3.5 & 1.3 & 1.2 & $\begin{array}{l}\mathrm{Fe}^{2+} \mathrm{Fe}_{2}^{3+} \mathrm{O}_{4} \\
\text { (Magnetite) }\end{array}$ \\
\hline EM-N1-27 & & & 16.9 & 6.7 & 4.5 & 25.7 & 6.2 & 3.3 & 3.2 & 3.1 & 2.6 & 4.2 & 2.3 & 1.9 & $\begin{array}{l}\mathrm{Fe}^{2+} \mathrm{Fe}^{3+}{ }_{2} \mathrm{O}_{4} \\
\text { (Magnetite) }\end{array}$ \\
\hline NP2-15 & $<0.5$ & $\mathrm{LiNi}_{0.5} \mathrm{Ti}_{0.5} \mathrm{O}_{2}$ & 19.7 & 2.2 & 2.6 & 28.3 & 2.9 & $<0.5$ & 2.9 & 3.1 & 2.9 & 3.4 & 3.4 & 2.6 & $\begin{array}{c}\mathrm{NiFe}_{2} \mathrm{O}_{4} \\
\text { (Trevorite) } \\
\end{array}$ \\
\hline NP2-11 & & & 19.4 & 21.4 & 6.1 & 21.8 & 16.3 & 5.3 & 5.9 & & & 5.4 & & & $\begin{array}{c}\mathrm{Li}_{2} \mathrm{SiO}_{3} \\
\text { (Lithium Silicate) }\end{array}$ \\
\hline HWI-ALS-03 & & & & & & & & & $<0.5$ & $<0.5$ & $<0.5$ & 1.2 & 1.4 & & $\begin{array}{c}\text { Maghemite } \\
\text { Trevorite } \\
\text { Magnetite } \\
\mathrm{LiFeTiO}_{4} \\
\end{array}$ \\
\hline $121506-07$ & & & & & & & & & 2.2 & 2.5 & 2.2 & 2.3 & 2.1 & 2 & $\begin{array}{c}\mathrm{NiFe}_{2} \mathrm{O}_{4} \\
\text { (Trevorite) }\end{array}$ \\
\hline $121506-08$ & 0.5 & $\mathrm{Fe}_{2.3} \mathrm{Si}_{0.7} \mathrm{O}_{4}$ & 2.8 & & & 4.6 & & & 3 & 2.8 & 3 & 2.5 & 2.8 & 2.3 & $\mathrm{Fe}_{2.3} \mathrm{Si}_{0.7} \mathrm{O}_{4}$ \\
\hline
\end{tabular}

" $<0.5$ " indicates that the phase was identified in XRD but in insufficient quantity to allow quantitative analysis. 


\subsubsection{NP2-02, EM-N1-24, EM-N1-25}

These glasses remained amorphous after all treatments indicating that these compositions are highly resistant to nepheline (or other) crystallization. Of note, EM-N1-24 and EM-N1-25 both have ND values less than the 0.62 limit, indicating that the ND is conservative for these glasses. Furthermore, the CCC-1 (or CCCR-1) kinetic state could be considered a worse kinetic state compared to the DWPF CCC kinetic state, which indicates a significant conservatism exists in the current ND as applied to these glasses.

\subsubsection{NP2-10, NP2-08}

These two glasses were also highly resistant to nepheline crystallization. NP2-10 contained $<0.5 \mathrm{wt} \%$ nepheline after CCCR-1 and NP2- 08 contained $<2 \mathrm{wt} \%$ lithium silicate after CCC- 1 and CCCR-1. Although these glasses are very resistant to nepheline crystallization, NP2-10 exposed to CCCR-1 treatment indicates that, given enough time, nepheline will form. It is also possible that the smooth cooling profile subjects the glass to more critical temperatures, times, and rates compared to the stepped cooling profiles. Further investigation is needed to separate/identify critical points in the different cooling profiles. Likewise, the same could be said for NP2-08 in regards to lithium silicate crystallization.

\subsubsection{NP2-25, NP2-22, NP2-23, EM-N1-26}

Nepheline was detected in all these glasses when cooled according to the CCC-1 or CCCR-1 schedules. The measured quantity of nepheline was as follows, NP2-25 $<$ NP2-22 $<$ NP2-23 $<$ EM-N1-26, for both CCC-1 and CCCR-1 schedules. No nepheline was detected in any of these glasses when cooled according to the CCC-5 or CCCR-5 schedules. However, NP2-22, NP2-23, and EM-N1-26 did exhibit nepheline crystallization when cooled according to the CCC-3 and CCCR-3 schedules. This is in agreement with the expected behavior of these glasses based on their ND values that were all $<0.62$. On the other hand, glass NP2-25 would appear to indicate conservatism in the current ND constraint since it did not precipitate nepheline after the CCC-3 treatment. In general, these results were anticipated since one would expect crystallization to increase with slower/longer cooling, indicating a kinetic effect. Secondary phases (nonnepheline) were also measured in some of these glasses although they were in very minor amounts and provide little additional information regarding crystal kinetics.

\subsubsection{EM-N1-19, EM-N1-27, NP2-15}

These were the only glasses in this study that precipitated nepheline in addition to a secondary phase after exposure to all six cooling treatments. This set of glasses is particularly useful to better understanding the impact of kinetics on nepheline formation. Figure 6 shows plots of the crystal content, for each of these glasses, as a function of total cooling time. Examination of these plots suggests that kinetics significantly affect the amount of nepheline in HLW glasses as evidenced by an increase in nepheline with increasing total cooling time. Furthermore, slopes of linear fits to the data vary among samples indicating that nepheline is precipitating at different rates depending on the glass composition.

It is interesting to note that in these glasses, there is a 'cross-over' point in which the amount of nepheline in the glasses subjected to smooth cooling schedules begins to significantly increase compared to the glasses subjected to stepped cooling schedules. The source of this phenomenon is not understood however, a probable explanation is that nepheline nucleation and/or growth occur at a critical temperature such that the stepped cooling schedule bypasses this critical temperature that is otherwise not bypassed by the smooth cooling schedule. Further investigation is needed to explore this observed trend. 
The secondary phase content is also shown for these glasses in Figure 6. EM-N1-19 and EM-N127 both precipitated magnetite and the results indicate that kinetics also impacts the amount of magnetite forming in these glasses albeit, to a lesser extent compared to nepheline. NP2-15 contained trevorite as a secondary phase. Unlike the other glasses, cooling schedule did not significantly impact the amount of trevorite. It is speculated that trevorite forms during high temperatures and growth is kinetically limited at lower temperatures.
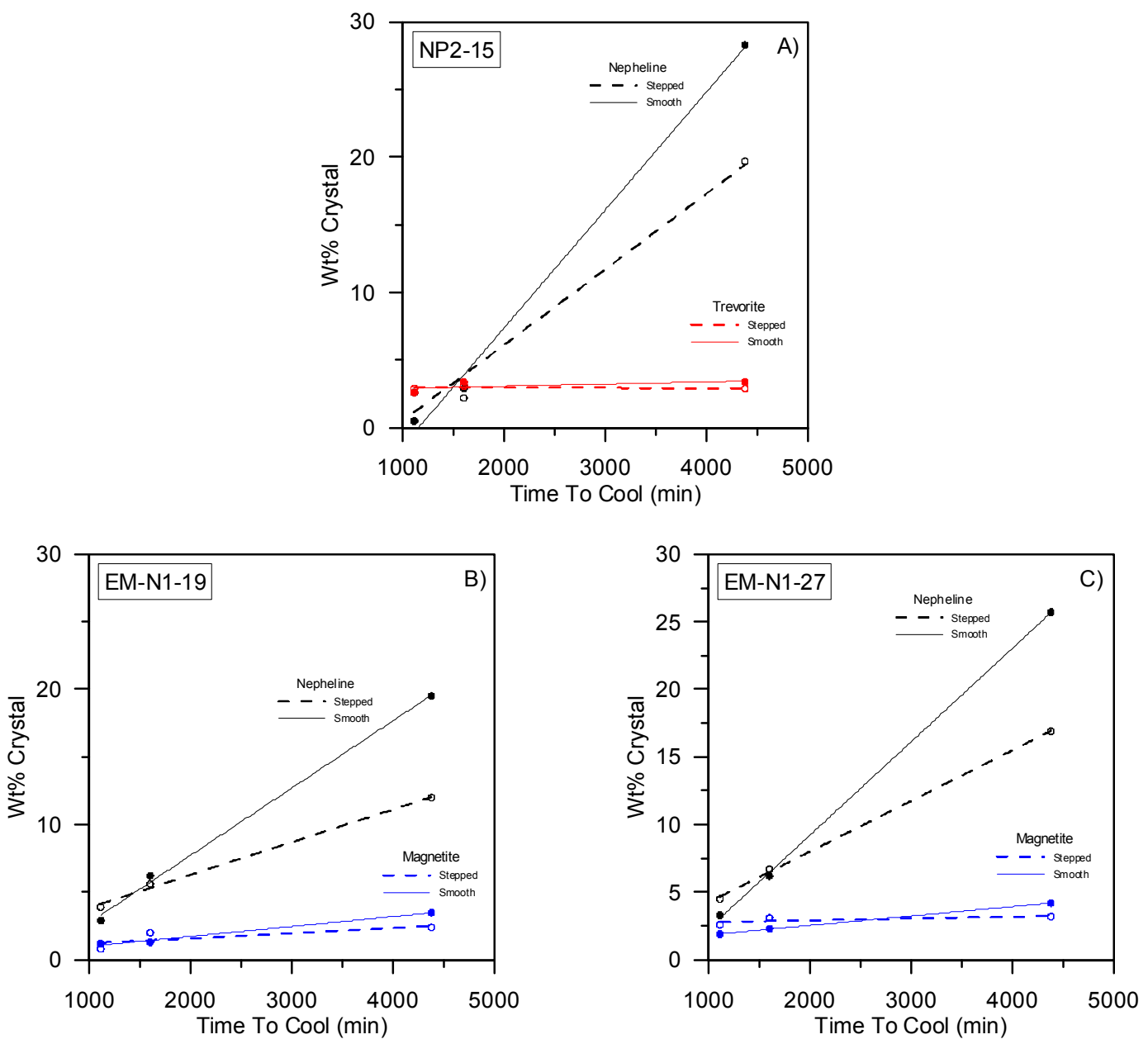

Figure 6. Percent Crystal Phases as a Function of Total Cooling Time for A) NP2-15, B) EM-N1-19, and C) EM-N1-27.

\subsubsection{NP2-11}

Although this glass might have been grouped with other glasses, this particular glass composition will be discussed separately because the kinetics appeared to be different compared to other glasses in this research. Figure 7 shows plots of the wt\% nepheline as a function of total cooling time and cooling rate for NP2-11. These plots suggest nepheline formation was inversely proportional to cooling rate for the NP2-11 glass composition, contrary to the previously discussed glass compositions, (NP2-15, EM-N1-19, and EM-N1-27) in which nepheline formation appeared to be proportional to the cooling duration (time). More investigations are needed to explain this result. 

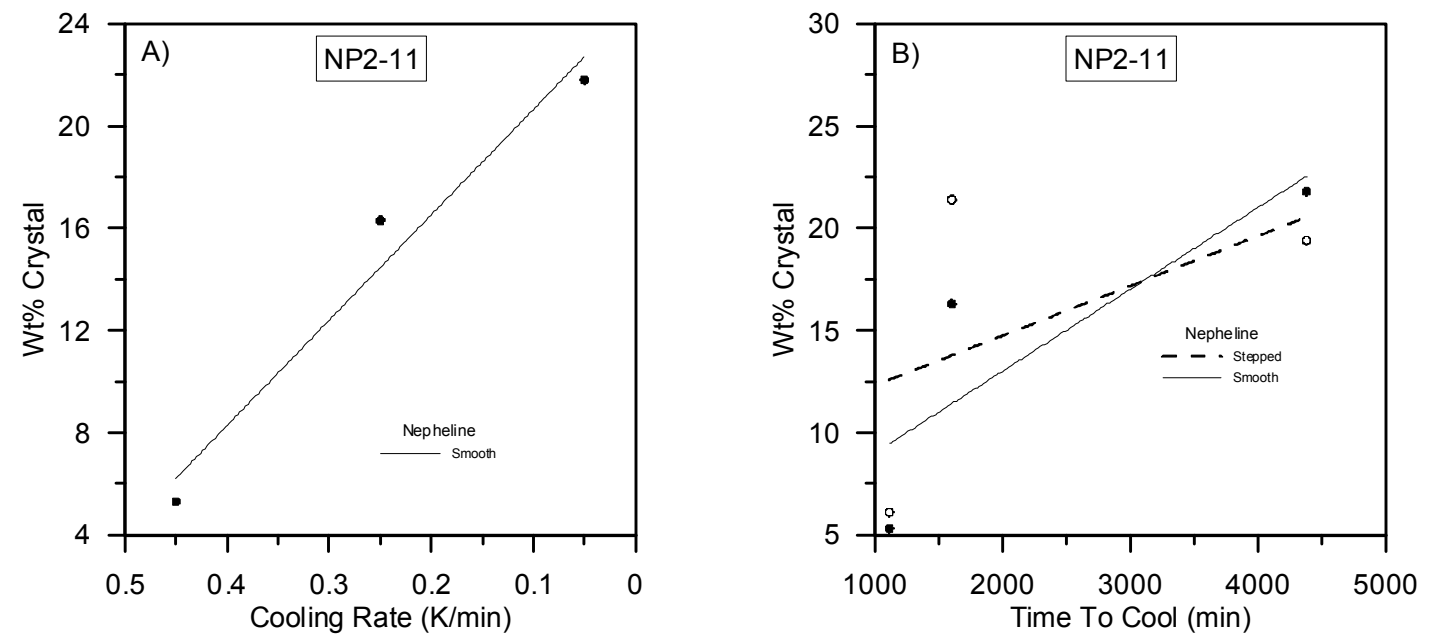

Figure 7. Percent Nepheline in NP2-11 After Cooling Treatments as a Function of A)

Cooling Rate* and B) Total Cooling Time. * This Plot could only be generated for the smooth schedules for obvious reasons. Additionally, because the rate was not constant throughout the cooling schedule, the rate was taken to be between 800 and $750{ }^{\circ} \mathrm{C}$, as described in Section 2.3. Incidentally, using the rate between 750 and $450{ }^{\circ} \mathrm{C}$ would not change the slope of the fit but, only shift it.

\subsubsection{HWI-ALS-03, 121506-07, 121506-08}

These glasses, high in alumina, generally contained spinel-like crystals after treatment with the exception of HWI-ALS-03 which was amorphous after the CCCR-5 treatment and 121506-08 which contained nepheline in addition to iron silicon oxide after CCC-1 and CCCR-1 treatments. These glasses all had ND values well below 0.62 but, were quite resistant to nepheline formation. The secondary phases found in these glasses were generally below $\sim 3 \mathrm{wt} \%$ and no significant trends in the amount of crystalline phase as a function of cooling treatment was evident. It was noted that these glasses were quite visually inhomogeneous compared to the other glasses in this study.

\subsubsection{Interior vs. Exterior (Center-Slice)}

As a point of clarification, in this section, the term 'glass' will be used interchangeably to refer to homogeneous glasses as well as inhomogeneous "glasses" which might contain surface crystallization around an otherwise glassy interior.

As was previously mentioned, it was speculated that the sampling location in glasses exposed to the DWPF CCC schedule affected the XRD results. Therefore, the interior of treated glasses in this study were expected to be microstructurally different than the exterior that was exposed to the atmosphere and/or the crucible wall. This phenomenon is shown in Figure 8A which illustrates a cross section of a glass inside a crucible after exposure to treatment and Figure $8 \mathrm{~B}$ which is a photograph of a thin section from glass NP2-22 after being exposed to the CCC-1 schedule. In Figure 8B definite microstructural difference between the interior and edges of the glass are clearly visible. (Note that the image in Figure $8 \mathrm{~B}$ does not represent a glass that was 'interior' sectioned. Rather, this glass was chosen as it illustrates the crystallization phenomenon well). 


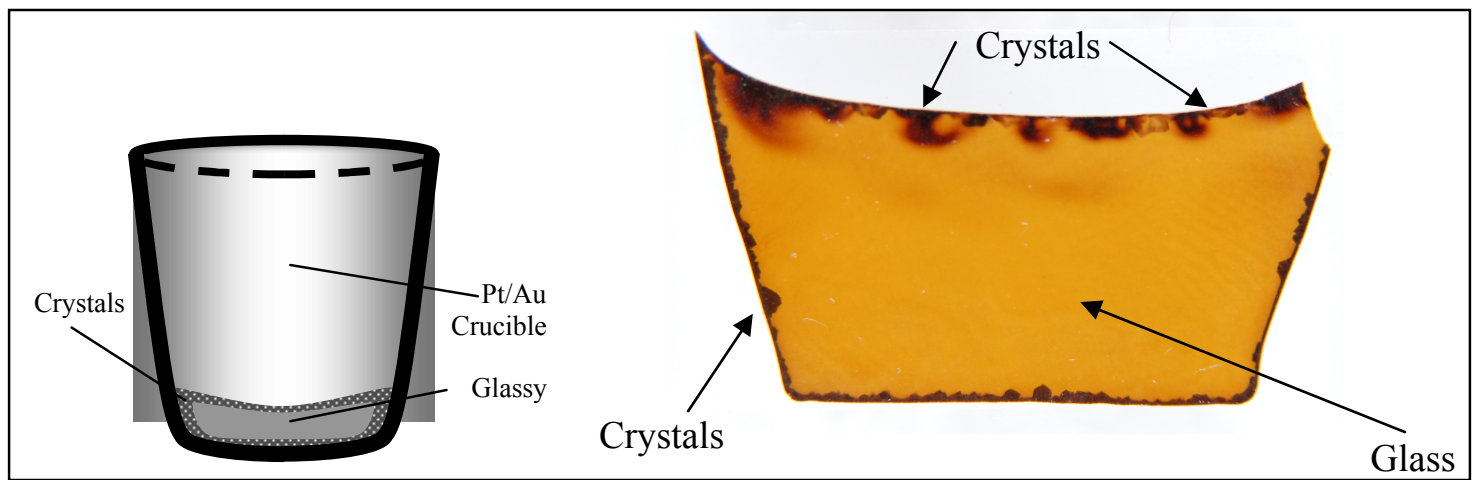

Figure 8. A) Schematic Representation of the Cross Section of a Glass in a Crucible After Cooling Treatment. B) Photograph of NP2-22 Thin Section After CCC-1 Treatment.

For glasses exposed to CCC-3 and CCCR-3 treatments, interior sections were taken from those glasses in which a crystalline phase(s) was detected in the center-slice section. (Note, interior sections were not measured for the high alumina glasses.) Glasses with amorphous center-slice sections were assumed to be amorphous at the interior as well. This was confirmed in several glasses. The qualitative XRD results for interior sections taken from those glasses exposed to CCC-3 and CCCR-3 schedules are summarized in Table 3-6. For all of these glasses, samples taken from the center of the treated glass did not contain nepheline. Moreover, for glasses in which secondary phases were measured in the center-slice sections, those same phases were also measured in the interior sections. Glass EM-N1-26 is an exception to this result. However, the amount of secondary phase measured in this glass from the center-slice section was below quantitative detection (see Table 3-2) and given that less material was available for interior sections compared to center-slice sections, it is possible that a secondary phase in the interior section of the EM-N1-26 glass would be below even a qualitative detection limit. Nevertheless, the results in Table 3-6 strongly indicate that nepheline nucleation and growth occur at the crucible walls and/or top surface of the glass during cooling. Although interior sections were not submitted for glasses that exhibited crystallization after CCC-1, CCCR-1, CCC-5, or CCCR-5 similar results are expected. However, it should be understood that because nepheline crystallization appeared to be independent of cooling rate in some instances, it is possible that nepheline would be observed in the center of some glasses (especially the slowest cooled glasses) purely because of the glass volume.

Table 3-6. Qualitative XRD Results for Interior and Center-Slice Sections for CCC-3 and CCCR-3 Cooling Treatments.

Center Slice

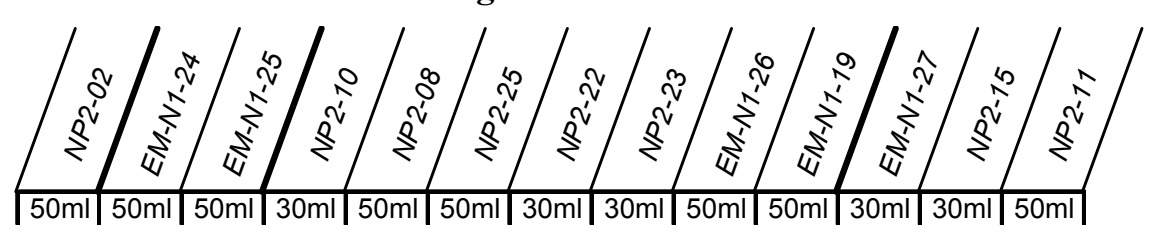

CCC-3 (stepped)

Interior

CCC-3 (stepped)

CCCR-3 (smooth)

key:

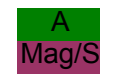

$=$
$=$

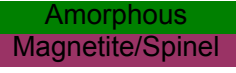




\subsection{Conclusions}

\subsection{Kinetics}

The kinetics of nepheline crystallization in HLW glasses is not consistent among glass compositions as evidenced by varying increases in crystallization with total cooling time. The rate of nepheline crystallization appeared to be independent of glass cooling rate albeit the crystallization rate appeared to vary depending on glass compositions. However, nepheline crystallization did appear to be proportional to the glass cooling rate in the case of the NP2-11 glass. These results indicate that the kinetic state of a glass during cooling affects nepheline crystallization. As currently implemented, the current ND is based on a single kinetic state (the DWPF CCC state) and appeared to be conservative for several glasses in this study. The potential exists for refining/modifying the current ND to incorporate kinetic effects, thus allowing access to functional compositional space that is necessary for increased aluminium and sodium loaded waste. It should be understood that these results are preliminary and further research is needed to confirm the relationships between nepheline crystallization, kinetics, and glass cooling rate/schedules.

In regard to the current DWPF CCC schedule, glasses exposed to stepped cooling schedules compared to smooth cooling schedules resulted in different amounts of crystallization. This difference was relatively minor at shorter total cooling times but increased significantly with longer cooling times.

\subsection{Nucleation/Growth}

Nepheline crystallization appeared to originate from the glass/crucible and glass/atmosphere interfaces. Although nepheline had been reported for some of these glasses previously, nepheline was not observed at the interior of any of the glasses exposed to CCC-3 or CCCR-3 schedules. Moreover, for these same glasses that contained secondary phases, the secondary phase was observed at the interior of the glass. Although quantitative results are pending at the time of this report, this suggests that although nepheline appears to nucleate from glass interfaces, the secondary phases do not. Rather, they are homogeneous throughout the glass and do not appear to be sources of nepheline nucleation. It is proposed that typical crucible-scale CCC experiments artificially induce nepheline crystallization in HLW glasses and that XRD data from those experiments may not represent homogeneous nucleation/crystallization. This nucleation effect is common and is the reason why the current $T_{L}$ procedure ${ }^{19}$ explicitly mentions analysis be performed from the interior of the glass.

The potential impact of these results is two-fold: 1) If nepheline does not readily nucleate from the canister material, then nepheline should not form inside the canister given current cooling schedules and 2) if the canister material does nucleate nepheline, because the canister wall is cooling faster than the centerline, nepheline also should not form inside the canister given current cooling schedules.

\subsection{Path Forward}

The study described here was a preliminary investigation into the impacts of kinetics on nepheline formation in HLW glasses. During this research it was found that several combined factors contributed to the overall kinetic state that a HLW glass experiences during processing at DWPF. Consequently, four areas of interest have been identified for further research: 


\section{Glass-surface interface effects}

Several different crucible types should be used to repeat the cooling treatments in this study (alumina, silica, and stainless steel type 304L) and the results compared to platinum/gold alloy crucibles used in this study.

\section{Nucleation/crystallization}

Nepheline nucleation and crystallization growth rates are needed to better understand the overall impact that cooling has on nepheline formation. This includes nucleation and growth temperatures as well as nucleation sites/agents.

\section{Canister modeling}

Develop a working computer model that can predict the glass temperature throughout the canister during pouring and cooling. In this way, hypothetical and/or anticipated pour conditions can be simulated to establish the various kinetic states throughout the glass in the canister during pouring and cooling.

\section{CCC crucible test}

During the course of investigating the previous suggestions, it may become prudent to modify or adjust the CCC experiment. If and when this becomes apparent, future recommendations will be made.

It is vital to communicate to the reader that the preceding recommendations are interdependent and need to be addressed collectively in order to draw appropriate conclusions. Subsequently, a determination can be made whether the ND as implemented has been overly conservative. Then it can be removed, and an alternative method for determining cooling impacts on the product acceptance can be established.

\subsection{References}

1. T. J. Menkhaus, P. Hrma and H. Li, "Kinetics of Nepheline Crystallization form HighLevel Waste Glass," Ceramic Transactions, 107 pp. 461-68, (2000).

2. H. Li, P. Hrma, J. D. Vienna, M. Qian, Y. Su and D. E. Smith, "Effects of $\mathrm{Al}_{2} \mathrm{O}_{3}, \mathrm{~B}_{2} \mathrm{O}_{3}$, $\mathrm{Na}_{2} \mathrm{O}$, and $\mathrm{SiO}_{2}$ on Nepheline Formation in Borosilicate Glasses: Chemical and Physical Correlations," Journal of Non-Crystalline Solids, 331 pp. 202-16, (2003).

3. H. Li, B. Jones, P. Hrma and J. D. Vienna, "Compositional Effects on Liquidus Temperature of Hanford Simulated High-Level Waste Glasses Precipitating Nepheline (NaAlSiO ${ }_{4}$ )," Ceramic Transactions, 87 pp. 279-88, (1998).

4. $\quad$ K. M. Fox and T. B. Edwards, "Experimental Results of the Nepheline Phase III Study," US Department of Energy Report SRNS-STI-2009-00608, Savannah River National Laboratory, Aiken, SC (2009). 
5. H. Li, J. D. Vienna, P. Hrma, D. E. Smith and M. J. Schweiger, "Nepheline Precipitation in High-Level Waste Glasses: Compositional Effects and Impact on the Waste Form Acceptability," Materials Research Soc. Symp. Proc., 465 pp. 261-68, (1997).

6. A. L. Billings, "EM-N1 Series Glasses (Effects of Increasing Waste Loading)," Preliminary Results, Savannah River National Laboratory, Aiken, SC (2010).

7. K. M. Fox and T. B. Edwards, "Refinement of the Nepheline Discriminator: Results of a Phase II Study," US Department of Energy Report SRNS-STI-2008-00099, Savannah River National Laboratory, Aiken, SC (2008).

8. K. M. Fox, J. D. Newell, R. E. Edwards, D. R. Best, I. A. Reamer and R. J. Workman, "Refinement of the Nepheline Discriminator: Results of a Phase I Study," US Department of Energy Report WSRC-STI-2007-00659, Savannah River National Laboratory, Aiken, SC (2007).

9. J. S. McCloy and J. D. Vienna, "Glass Composition Constraint Recommendations for Use in Life-Cycle Mission Modeling," US Department of Energy Report PNNL-19372, Pacific Northwest National Laboratory, Richland, Washington (2010).

10. K. M. Fox and D. K. Peeler, "Deomonstration of Very High Aluminum Retention in Simulated HLW Glass," Inter-Office Memorandum SRNL-PSE-2007-00231, Savannah River National Laboratory, Aiken, SC (2007).

11. W. K. Kot and I. L. Pegg, "Glass Formulation Development and Testing for DWPF High$\mathrm{Al}_{2} \mathrm{O}_{3}$ HLW Sludges," Data Summary Report VSL-10S1670-1, Vitreous State Laboratory, Washington, DC (2010).

12. SRNL, "Glass Batching," Manual L29 Procedure ITS-0001, Rev. 1, Savannah River National Laboratory, Aiken, SC (2007).

13. SRNL, "Glass Melting," Manual L29 Procedure ITS-0003, Rev. 2, Savannah River National Laboratory, Aiken, SC (2007).

14. R. E. Edwards, "SGM 8 - Canister and Glass Temperatures During Filling and Cooldown," Inter-Office Memorandum WSRC-IM-91-116-1, Westinghouse Savannah River Company, Aiken, SC (1987).

15. A. L. Billings and T. B. Edwards, "Time-Temperature-Transformation (TTT) Diagrams for The Sludge Batch 3 - Frit 418 Glass System," US Department of Energy Report SRNL-STI-2009-00025, Savannah River National Laboratory, Aiken, SC (2009).

16. C. A. Cicero, S. L. Marra and M. K. Andrews, "Phase Stability Determinations of DWPF Waste Glasses," US Department of Energy Report WSRC-TR-93-227, Rev. 0, Westinghouse Savannah River Company, Aiken, SC (1993).

17. S. L. Marra and C. M. Jantzen, "Characterization of Projected DWPF Glasses Heat Treated to Simulate Canister Centerline Cooling," US Department of Energy Report WSRC-TR-92-142, Rev. 0, Westinghouse Savannah River Company, Aiken, SC (1992). 
18. C. P. Rodriguez, J. S. McCloy, M. J. Schweiger, J. V. Crum and A. Winschell, "Optical Basicity and Nepheline Crystallization in High Alumina Glasses," Department of Energy Report PNNL-20184, Pacific Northwest National Laboratory, Richland, Washington (2011).

19. SRNL, "Isothermal Liquidus Temperature Measurement," Manual L29 Procedure ITS0025, Rev. 1, Savannah River National Laboratory, Aiken, SC (2007). 


\section{ACKNOWLEDGEMENTS}

The author would like to thank Irene Reamer, Phyllis Workman, David Best, Whitney Riley, and David Missimer at SRNL for their assistance with characterizing the study glasses. The author acknowledges the U.S. Department of Energy Office of Environmental Management for financial support of this work. 


\section{Distribution:}

J. W. Amoroso, 999-W

A. B. Barnes, 999-W

A. L. Billings, 999-W

C. L. Crawford, 773-42A

D. A. Crowley, 773-43A

A. P. Fellinger, 773-41A

S. D. Fink, 773-A

K. M. Fox, 999-W

B. J. Giddings, 786-5A

C. C. Herman, 999-W

C. M. Jantzen, 773-A

F. C. Johnson, 999-W

S. L. Marra, 773-A

D. K. Peeler, 999-W

F. M. Pennebaker, 773-42A

M. E. Stone, 999-W

W. R. Wilmarth, 773-A 